\section{Регулирующее действие света на растения}

Ю.Н. Кульчин ${ }^{1,2}$, Д. О. Гольщова ${ }^{1}$, Е. П. Субботин ${ }^{1}$

1 Институт автоматики и прощессов управления ДВО РАН, Владивосток, Россия

2 Дальневосточный федеральный университет, Владивосток, Россия

\section{В статье рассматриваются вопросы световой регуляции генетической системы растений и светового управления морфогенезом. Дано представление о механизмах трансляции светового сигнала в клетке. Показана взаимосвязь между фоторецепторными белками и эндогенными программами развития растений. Охарактеризована роль пигментных белков и фитогормонов в процессах регуляция онтогенеза растений. Приведены экспериментальные результаты, демонстрирующие световое управление морфогенезом растений.}

Ключевые слова: свет, спектр излучения, световое управление, пигментные белки, фитогормоны, фоторцеция, онтогенез растений

Статья получена: 09.09.2019 Статья принята к публикации: 07.10.2019

\section{ВВЕДЕНИЕ}

Солнечный свет - важный адаптационный стимул, и многие живые организмы приспосабливают свой метаболизм к условиям изменяемой освещенности в окружающей среде, воспринимая световые сигналы и реагируя на них изменением своих физиологических функций [1]. При этом свет выступает многогранным фактором, характеризу ющимся качественными (диапазоном длин волн) и количественными (интенсивностью, интеграль ной суточной радиацией, фотопериодом) параме трами, а также направлением и поляризацией. Как правило, основная причина низкой продуктивности растущих в естественных условиях растений заключается в том, что громадное количество поступающей от Солнца энергии обесценивается как фактор фотосинтеза вследствие неблагоприят-

\section{Regulating Effect of Light on Plants}

\author{
Yu. N. Kulchin ${ }^{1,2}$, D. O. Goltsova' , E. P. Subbotin ${ }^{1}$ \\ ${ }^{1}$ Institute of automation and control processes FEB RAS \\ ${ }^{2}$ Far Eastern Federal University, Vladivostok, Russia
}

The article deals with the issues of light regulation of the plant genetic system and light control of morphogenesis. The idea of the mechanisms of light signal translation in the cell is given. The relationship between photoreceptor proteins and endogenous programs of plant development is shown. The role of pigment proteins and phytohormones in the regulation of plant ontogenesis is characterized. Experimental results demonstrating light control of plant morphogenesis are presented.

Keywords: light, light control, spectrum, pigment proteins, photoreception, phytohormones, plants ontogenesis.

Received: 09.09.2019 Accepted: 07.10.2019

\section{INTRODUCTION}

Sunlight is an important adaptive stimulus, and many living organisms adapt their metabolism to the conditions of variable lighting in the environment, perceiving and reacting to light signals by changing their physiological functions [1]. In this case, light acts as a multifaceted factor characterized by qualitative (range of wavelengths) and quantitative (intensity, integral daily radiation, photoperiod) parameters, as well as direction and polarization As a rule, the main reason for the low productivity of plants growing under natural conditions is that a huge amount of energy coming from the Sun is depreciated as a factor in photosynthesis due to unfavorable combinations of lighting parameters with other productivity conditions: heat, humidity, and soil fertility conditions [2]. Given that light controls the functioning of endogenous regulation systems (gene, enzymatic, trophic, hormonal, etc.), the combined effect of which provides an adequate response of plants to lighting conditions, by manipulating the characteristics of lighting, it 
ных сочетаний параметров освещения с другими условиями продуктивности: теплом, влажностью и условиями почвенного плодородия [2]. Учиты вая, что свет контролирует функционирование систем эндогенной регуляции (генной, ферментативной, трофической, гормональной и т.п.), совокупное действие которых обеспечивает адекватную реакцию растений на условия освещения, можно, манипулируя характеристиками освещения, максимально раскрыть потенциал, определяемый генетическим планом растения. Тем самым, используя различные части спектра, можно задавать растению входные данные, или "инструкции", которые приведут к предсказуемым биохимическим событиям и ощутимым управляемым практическим результатам. В данном случае наблюдаемые эффекты управления морфогенезом растений, основанные на использовании различных спектров освещения, в некотором смысле родственны генной модификации, но при этом не изменяют самого генофонда растения [3].

Идея использования разных спектральных компонент света для управления развитием растений не нова. Но чтобы понять, почему этот подход возможен, необходимо знать, как формируются отклики растений в результате экспрессии разных генов под воздействием света. Эти исследования представляют огромный интерес, так как открывают возможность максимального раскрытия генетического потенциала культур растений без генетической модификации или увеличения использования химических веществ. Цель настоящей работы заключается в рассмотрении вопросов, связанных со световым управлением морфогенезом растений.

\section{1. ПИГМЕНТНЫЕ БЕЛКИ В ОНТОГЕНЕЗЕ РАСТЕНИЙ}

Для того чтобы свет мог оказывать влияние на растительные организмы и, в частности, использоваться в процессе фотосинтеза, необходимо его поглощение фоточувствительными белками (антеннами) - пигментами [4], осуществляющими избирательное поглощение света. Пигменты играют важную и разнообразную роль в жизнеде ятельности организмов, особенно в протекающих в них фотобиологических процессах.

Главный фотобиологический процесс - фотосинтез, в ходе которого энергия электромагнитного излучения превращается в химическую энергию органических соединений [5].

Набор, состав и соотношение пигментов специфичны для различных групп организмов [6]. Пиг- is possible to maximize the potential determined by the genetic plan of the plant. Thus, using various parts of the spectrum, it is possible to give input data, or "instructions", to the plant which will lead to predictable biochemical events and tangible controlled practical results. In this case, the observed effects of controlling plant morphogenesis, based on the use of different lighting spectra, are in a sense related to gene modification, but do not change the plant's gene pool itself [3].

The idea of using different spectral components of light to control plant development is not new. However, in order to understand why this approach is possible, it is necessary to know how plant responses are formed as a result of the expression of different genes under the influence of light. These studies are of great interest, since they open up the possibility of maximizing the genetic potential of plant crops without genetic modification or increased use of chemicals. The purpose of this article is to consider issues related to the light control of plant morphogenesis.

\section{PIGMENT PROTEINS IN PLANT ONTOGENESIS}

In order for light to influence plant organisms and, in particular, to be used in the process of photosynthesis, it is necessary to absorb it with photosensitive proteins (antennas), i.e. pigments [4], which selectively absorb light. Th pigments play an important and diverse role in the life of organisms, especially in their photobiological processes.

The main photobiological process is photosynthesis, during which the energy of electromagnetic radiation is converted into the chemical energy of organic compounds [5].

The set, composition and ratio of pigments are specific for various groups of organisms [6]. Pigments of photosynthesis in higher plants are concentrated in plastids. They can be divided into four groups: chlorophylls, carotenoids, phycobilins, and flavonoids $[7,8]$.

Chlorophylls play a crucial role in the process of photosynthesis [9]. All higher plants contain chlorophylls $a$ and $b$. Chlorophyll $a$ in a solution has an absorption maximum at wavelengths of 440 and $700 \mathrm{~nm}$, and chlorophyll $b$ - at wavelengths of 460 and $660 \mathrm{~nm}$. However, there are forms of chlorophyll that absorb light at a wavelength of 642,710 , and even $720 \mathrm{~nm}$. The synthesis of chlorophyll is a multi-stage process proceeding with the participation of various enzymes, the 
менты фотосинтеза у высших растений сконцентрированы в пластидах. Их можно разделить на четыре группы: хлорофиллы, каротиноиды, фикобилины и флавоноиды $[7,8]$.

Хлорофиллы играют важнейшую роль в процессе фотосинтеза [9].У всех высших растений содержатся хлорофиллы $a$ и $b$. Хлорофилл $a$ в рас творе имеет максимум поглощения на длинах волн 440 и 700 нм, а хлорофилл $b$ - на длинах волн 460 и 660 нм. Однако есть формы хлорофилла, поглощающие свет с длиной волны 642, 710 и даже 720 нм. Синтез хлорофилла - многоэтапный процесс, протекающий с участием различных фер ментов, образование которых ускоряется на свету. При исследовании влияния света на образование хлорофилла в большинстве случаев проявилась положительная роль красного света. Большое значение имеет также интенсивность освещения Существуют нижний и верхний пределы интен сивности освещенности растений, начиная с которых образование хлорофилла тормозится.

Наряду с зелеными пигментами в хлоропластах и хроматофорах содержатся пигменты, относящиеся к группе каротиноидов. Каротиноиды - это желтые и оранжевые пигменты. Они присутствуют у всех высших растений и у многих микроорганиз мов [10]. Основными представителями каротиноидов у высших растений являются два пигмента $\beta$-каротин (оранжевый) и ксантофилл (желтый). $\beta$-каротин имеет два максимума поглощения, соответствующие длинам волн 452 и $482 \mathrm{Hм}$, а ксантофилл - на длинах волн 470 и 502 нм. Установлено, что каротиноиды, поглощая определенные участки солнечного спектра, передают энергию этих лучей на молекулы хлорофилла и тем самым способствуют использованию спектрального диа пазона света, который хлорофиллом не поглоща ется. Имеются данные, что каротиноиды также выполняют защитную функцию, предохраняя различные органические вещества клеток растений, в первую очередь молекулы хлорофилла, от разрушения на свету в процессе фотоокисления. При формировании листьев каротиноиды образуются и накапливаются в пластидах и не требуют света при синтезе.

Фикобилины - красные и синие пигменты, присутствующие у цианобактерий и некоторых водорослей [11]. Они представлены следующими пигментами: фикоцианином, фикоэритрином и аллофикоцианином. Фикобилины поглощают лучи в зеленой и желтой частях спектра свето вого излучения. Это та часть спектра, которая находится между двумя основными линиями formation of which is accelerated in the light. In the study of the effect of light on the formation of chlorophyll, in most cases the positive role of red light has been prominent. The intensity of lighting is also of great importance. There are lower and upper limits on the intensity of lighting of plants, starting from which the formation of chlorophyll is inhibited.

Along with green pigments, chloroplasts and chromatophores contain pigments belonging to the group of carotenoids. Carotenoids are yellow and orange pigments. They are present in all higher plants and in many microorganisms [10]. The main representatives of carotenoids in higher plants are two pigments - $\beta$-carotene (orange) and xanthophyll (yellow). $\beta$-carotene has two absorption maxima corresponding to wavelengths of 452 and $482 \mathrm{~nm}$, and xanthophyll - at wavelengths of 470 and 502 $\mathrm{nm}$. It was established that carotenoids, absorbing certain parts of the solar spectrum, transfer the energy of these rays to chlorophyll molecules and thereby contribute to the use of the spectral range of light that is not absorbed by chlorophyll. There is evidence that carotenoids also perform a protective function, protecting various organic substances of plant cells, primarily chlorophyll molecules, from destruction in the light during photooxidation. During leaf formation, carotenoids are formed and accumulate in plastids, and do not require light during synthesis.

Phycobilins are red and blue pigments present in cyanobacteria and some algae [11]. They are presented as the following pigments: phycocyanin, phycoerythrin and allophycocyanin. Phycobilins absorb rays in the green and yellow parts of the spectrum of light radiation. This is the part of the spectrum that lies between the two main absorption lines of chlorophyll. Phycoerythrin absorbs rays with a wavelength of 495-565 nm, and phycocyanin - at 550-615 nm. It is believed that phycobilins absorb the energy of light and, like carotenoids, transmit it to the chlorophyll molecule, after which it is used in photosynthesis.

Flavonoids are the largest class of plant pigments found in the form of glycosides in moisture of plants. These include anthocyanins, anthocyanidins, aurons, dihydrochalcones, isoflavones, catechins, leukoanthocyanidins, flavononols, flavones, flavanones, flavonols and chalcones. Depending on the $\mathrm{pH}$ of the medium, flavonoids have red, yellow, blue and violet color. They take part in photosynthesis, lignin formation, and are involved 
поглощения хлорофилла. Фикоэритрин поглощает лучи с длиной волны 495-565 нм, а фикоцианин - 550-615 нм. Считается, что фикобилины поглощают энергию света и, подобно каротинои дам, передают ее на молекулу хлорофилла, после чего она используется в процессе фотосинтеза.

Флавоноиды - крупнейший класс растительных пигментов, находящихся в виде гликозидов в соке растений. К ним относят антоцианы, антоцианидины, ауроны, дигидрохалконы, изофлавоны, катехины, лейкоантоцианидины, флавононолы, флавоны, флаваноны, флавонолы и халконы. В зависимости от РН среды флавоноиды имеют красную, желтую, синюю и фиолетовую окраску. Они принимают участие в фотосинтезе, образовании лигнина, вовлечены в регуляцию процессов прорастания семян, пролиферации и отмирания (путем апоптоза) клеток [12, 13].

Известно, что успешная закладка генеративных структур и вызревание плодов, семян и других хозяйственно ценных органов культурных растений во многом зависят от регуляции этих процессов, в которых задействовано множество генных комплексов. В настоящее время ясно, что размер и стабильность антенн фотосинтетического аппарата важны не только для фотосинтетической функции, но и для осуществления регуляторных сигналов, распространяющихся за пределы хлоропластов клеток растений [14].

В ходе онтогенеза клетки растений должны эффективно координировать активность двух геномов - ядерного и пластидного. Такая координация оказывается возможной благодаря существованию двух противоположно направленных процессов. С одной стороны, это ядерный контроль над экспрессией генома хлоропластов, с другой это обратная регуляция, направленная от хлоропластов к ядру, несущая информацию о состоянии и функционировании этих органелл в данных конкретных условиях и обеспечивающая таким образом обратную связь между цитоплазмой и ядром. В данном случае при изменении спектрального состава или интенсивности освещения меняется стехиометрический состав белков светособирающих комплексов хлоропластов, а также интенсивность процессов биосинтеза хлорофиллов, каротиноидов, фикобилинов и флавоноидов. Практически все вовлеченные в осуществление этих процессов белки кодируются в ядре. В связи с этим информация об изменении спектрального состава или интенсивности освещения должна поступать в ядро от хлоропластов и приводить к изменению экспрессии соответствующих ядер- in the regulation of seed germination, proliferation, and cell death (by apoptosis) [12, 13].

It is known that the successful laying of generative structures and the ripening of fruits, seeds and other economically valuable organs of cultivated plants largely depend on the regulation of these processes, which involve numerous gene complexes. It is now clear that the size and stability of the antennas of the photosynthetic apparatus are important not only for the photosynthetic function, but also for the implementation of regulatory signals propagating beyond the chloroplasts of the plant cells [14].

During ontogenesis, plant cells should effectively coordinate the activity of two genomes - nuclear and plastid. Such coordination is possible due to the existence of two oppositely directed processes. On the one hand, there is a nuclear control over the expression of the genome of chloroplasts, on the other hand, there is reverse regulation directed from chloroplasts to the nucleus, which carries information on the state and functioning of these organelles under the specific conditions, and thus provides feedback between the cytoplasm and the nucleus. In this case, with a change in the spectral composition or light intensity, the stoichiometric composition of the proteins of the light-harvesting complexes of chloroplasts, as well as the intensity of the biosynthesis of chlorophylls, carotenoids, phycobilins and flavonoids, change. Almost all proteins involved in the implementation of these processes are encoded in the nucleus. In this regard, information on changes in the spectral composition or intensity of lighting should enter the nucleus from chloroplasts and lead to a change in the expression of the corresponding nuclear genes. The specific mechanisms of generation and transmission of plastid-nuclear signals in plants have not been studied to date. It is believed that such signals are reactive oxygen species generated with the participation of plastid-bound proteins, which, through a series of cascades with the participation of more stable forms of compounds, ensure the transmission of information through the cytoplasm to the nucleus $[15,16]$.

\section{PLANT PHOTOMORPHOGENESIS}

Plant growth and development are controlled by genetic determinants, their expression products, and environmental signals. The physiological effects of light signals in plants are very differentiated: light is a unique source of energy that provides photosynthesis, but it also has a powerful 
ных генов. Конкретные механизмы генерации и передачи пластидно-ядерных сигналов у расте ний изучены на сегодняшний день недостаточно. Считается, что такими сигналами являются актив ные формы кислорода, генерируемые при участии связанных с пластидами белков, которые посредством ряда каскадов с участием более стабильных форм соединений обеспечивают передачу инфор мации через цитоплазму в ядро $[15,16]$.

\section{2. ФОТОМОРФОГЕНЕЗ РАСТЕНИЙ}

Рост и развитие растений контролируются генетическими детерминантами, продуктами их экспрессии и сигналами внешней среды. Физиологические эффекты световых сигналов в растениях весьма дифференцированы: свет является уникальным источником энергии, обеспечивающим фотосинтез, но он также оказывает мощное стимулирующее влияние на морфогенез растений [1] Фоторецепция - важнейшая функция, необходи мая растениям для приспособления к условиям освещения и другим параметрам среды, ибо свет служит для них синхронизатором суточных и сезонных биоритмов, а также источником специфической сигнальной информации [17]. Морфоге нез растений, который управляется параметрами освещения, называется фотоморфогенезом [18].

На сегодняшний день общепринятыми считаются несколько механизмов регуляторного влияния света на растения, действие которых может носить как изолированный, так и совместный характер [16]:

- непосредственное действие светового излучения на генетический аппарат растений через возбуждение фоторецепторов, которое способствует синтезу необходимых белков;

- эндогенная регуляция, проявляющаяся через возбуждение светом фоторецепторов активности фитогормонов, которые являются одними из ближайших к фотохромным белкам звеньев регуляторной системы в клетках растений;

- влияние света на функциональную активность клеточных мембран, осуществляемое через изменение электрических характери стик мембран клеток и тканей, облучаемых светом органов растений, что вызывает опре деленные физиологические эффекты: новооб разование фитогормонов и активацию неко торых генов.

Вследствие эволюционной адаптации к изменяющимся и экстремальным условиям освещенности растения имеют усложненную специализирован stimulating effect on plant morphogenesis [1]. Photoreception is the most important function necessary for plants to adapt to lighting conditions and other environmental parameters, because light serves as a synchronizer of daily and seasonal biorhythms for them, as well as a source of specific signaling information [17]. Plant morphogenesis, which is controlled by lighting parameters, is called photomorphogenesis [18].

Today, several mechanisms of the regulatory influence of light on plants are considered generally accepted, the action of which can be both isolated or joint [16]:

- the direct effect of light radiation on the genetic apparatus of plants through the excitation of photoreceptors, which contributes to the synthesis of necessary proteins;

- endogenous regulation, manifested through the excitation by light of photoreceptors of the activity of phytohormones, which are one of the links of the regulatory system closest to photochromic proteins in plant cells;

- the effect of light on the functional activity of cell membranes, carried out through a change in the electrical characteristics of the membranes of cells and tissues illuminated with light from plant organs, which causes certain physiological effects: the formation of phytohormones and the activation of certain genes.

Due to evolutionary adaptation to changing and extreme lighting conditions, plants have a sophisticated specialized photoreceptor network. In plants with the most developed light reception system responsible for the implementation of a variety of photoresponders, several types of regulatory photoreceptor proteins (photoreceptors) function, the spectral sensitivity of which allows for controlling morphogenesis of practically all areas of the optical spectrum. These include phytochromes, sensors of red (R) and far red (FR) light (operating range of 600-750 nm); cryptochroms and phototropins, receptors of near-ultraviolet (UVA) and blue (B) light (operating range of 320-500 $\mathrm{nm}$ ); as well as the UVR8 protein, a photon receptor in the far ultraviolet region of the spectrum (UV-B) (operating range of 290-320 nm) [19].

The expression of light-regulated genes in plants is controlled by various classes of photoreceptors $[20,21]$, which transform light signals into biochemical signaling cascades that cause physiological cellular responses. The photon sensors of photoreceptor proteins are chromophore 
ную фоторецепторную сеть. У растений с наиболее развитой системой рецепции света, ответственной за реализацию разнообразных фотоответов, функ ционирует несколько типов регуляторных фоторе цепторных белков (фоторецепторов), спектральная чувствительность которых позволяет использовать для управления морфогенезом практически все области оптического спектра. К ним относятся фитохромы - сенсоры красного (R) и дальнего красного (FR) света (область функционирования 600750 нм), криптохромы и фототропины - рецепторы ближнего ультрафиолетового (UV-A) и синего (В) света (область функционирования 320-500 нм), а также белок UVR8 - рецептор фотонов дальней ультрафиолетовой области спектра (UV-B) (область функционирования 290-320 нм) [19].

Экспрессия светорегулируемых генов у растений контролируется различными классами фоторецеп торов $[20,21]$, которые трансформируют световые сигналы в биохимические сигнальные каскады, вызывающие физиологические клеточные ответы. Сенсорами фотонов у фоторецепторных белков служат молекулы хромофоров, фотопревращение которых инициирует структурные изменения в фотосенсорном домене с последующей трансдукцией сигнала к эффекторным доменам фоторецепторов или взаимодействующим белкам, вызывая модуляцию их активности.

Таким образом, основой фотоморфогенеза растений является детектирование специальными фоточувствительными образованиями - фоторецепторными белками (фоторецепторами) - наличия или отсутствия световой энергии заданной интенсивности в заданном диапазоне длин волн. Предполагается, что световые сигналы, принятые фоторецепторами, должны быть преобразованы и далее должны передаваться через фоторегуля торные системы, вызывая экспрессию генов, что в конечном итоге приводит к физиологическому ответу. Доказано, что растительные гормоны через систему фоторецепции также вовлечены в реак цию на свет. В результате при обнаружении задан ных изменений параметров света фоторецептор запускает цепочку биохимических процессов, активирующих в конечном итоге требуемую реакцию организма растения (рис. 1).

Взаимосвязь между фоторецепторными белками и эндогенными программами развития растений заключается в их влиянии на рост и развитие клеток, которое проявляется в регуляции движения хлоропластов, изменении проницаемости мембран, синтезе ферментов и фитогормонов. При этом предполагается, что поглощенный molecules, the photoconversion of which initiates structural changes in the photosensory domain, followed by signal transduction to the effector domains of the photoreceptors or interacting proteins, causing modulation of their activity.

Thus, the basis of plant photomorphogenesis is the detection by special photosensitive formations photoreceptor proteins (photoreceptors) - of the presence or absence of light energy of a given intensity in a given wavelength range. It is assumed that the light signals received by photoreceptors must be converted and then transmitted through photoregulatory systems, causing gene expression, which ultimately leads to a physiological response. It has been proven that plant hormones, through the photoreception system, are also involved in the reaction to light. As a result, when predetermined changes in the parameters of light are detected, the photoreceptor starts a chain of biochemical processes that ultimately activate the desired reaction of the plant organism (Fig. 1).

The relationship between photoreceptor proteins and endogenous plant development programs is their effect on cell growth and development, which is manifested in the regulation of chloroplast movement, changes in membrane permeability, and the synthesis of enzymes and phytohormones. It is assumed that the absorbed quantum (or several quanta) of light converts the photoreceptor protein into an active form. Subsequently, a certain signal is generated that enters the cell nucleus to DNA, which derepresses the potentially active gene, bringing it into an active state, which results in switching in the matrix synthesis of messenger RNA (mRNA) and proteins.

Phytochrome genes are found in nuclear DNA. Therefore, gene expression is carried out in the nucleus, and phytochrome protein synthesis is carried out in cytoplasmic ribosomes. Phytochromobilin (phytochrome chromophore) is synthesized in plastids, and only then enters the cytoplasm. Autocatalytic covalent attachment of the chromophore to the phytochrome protein takes place in the cytoplasm. As a result, a functionally active phytochrome molecule is formed [22].

Thus, there is a two-way relationship between the signal systems and the plant genome: on the one hand, the proteins of the signal systems are encoded in the genome, and on the other, the signal systems control the genome, expressing or inhibiting the activity of other genes. Therefore, studies related to the study of plant signaling systems are intensively developing [3]. 

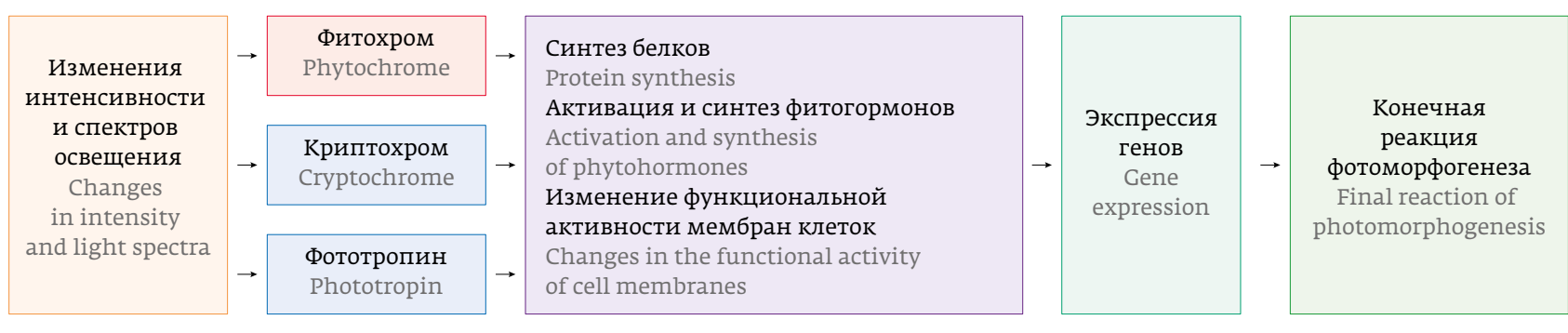

Puc. 1. Предполагаемая схема процесса фотоморфогенеза у растений

Fig. 1. Proposed scheme of photomorphogenesis process in plants

квант (или несколько квантов) света переводит фоторецепторный белок в активную форму. В даль нейшем генерируется некий сигнал, поступающий в ядро клетки к ДНК, который дерепрессирует потенциально активный ген, приводя его в актив ное состояние, в результате чего происходит переключение в матричном синтезе информационной РНК (иРНК) и белков.

Гены фитохромов находятся в ядерной ДНК. Поэтому экспрессия генов осуществляется в ядре, а синтез белков фитохромов - в цитоплазматических рибосомах. Фитохромобилин (хромофор фитохрома) синтезируется в пластидах, а уже потом поступает в цитоплазму. В цитоплазме происходит автокаталитическое ковалентное присоединение хромофора к белку фитохрома. В резуль тате образуется функционально активная молекула фитохрома [22].

Таким образом, между сигнальными системами и геномом растений существует двусторонняя связь: с одной стороны, белки сигнальных систем закодированы в геноме, с другой - сигналь ные системы управляют геномом, экспрессируя или подавляя активность других генов. Поэтому исследования, связанные с изучением сигнальных систем растений, интенсивно развиваются [3].

\section{3. ФИТОГОРМОНАЛЬНАЯ РЕГУЛЯЦИЯ ОНТОГЕНЕЗА РАСТЕНИЙ}

Синтезируемые в клетках растений фитогормоны - низкомолекулярные органические вещества, вырабатываемые растениями и име ющие регуляторные функции. Фитогормоны вызывают различные физиологические и мор фологические изменения в чувствительных к их действию частях растений. Вещества, традиционно считающиеся фитогормонами, - ауксины, гиббереллины, цитокинины, этилен, брасси ностероиды и абсцизовая кислота. Часто к ним

\section{PHYTOHORMONAL REGULATION OF PLANT ONTOGENESIS}

The phytohormones synthesized in plant cells are low-molecular organic substances produced by plants and having regulatory functions. Phytohormones cause various physiological and morphological changes in parts of plants sensitive to their action. Substances traditionally considered phytohormones are auxins, gibberellins, cytokinins, ethylene, brassinosteroids and abscisic acid. Often, jasmonic and salicylic acids and some phenolic compounds are added to them $[23,24]$.

Unlike animals, plants do not have special organs that synthesize hormones. However, some of their organs are more saturated with hormones compared to others. For example, apical stem meristems and the apical part of the root are enriched with auxins [25], abscisins usually act at the synthesis point, spreading only a short distance, and ethylene is transported only as a precursor [26].

Phytohormones have a wide spectrum of action and coordinate between individual cells and plant tissues. They regulate many processes of plant life: seed germination, growth, differentiation of tissues and organs, flowering and ripening of fruits. Forming in one organ (or its part) of a plant, phytohormones are usually transported to another organ (or its part). Exogenous phytohormones penetrate the plants quite evenly, and endogenous are localized in separate cell depots. Therefore, hormonal "feeding" of plants from the outside does not replace the natural synthesis of phytohormones and is able to help plants only under certain conditions, and therefore it is necessary to develop a controlled process for the synthesis of phytohormones.

The phytohormonal regulatory effect on plant growth and development is achieved in two ways: by changing the dose of phytohormone and the 
добавляют жасмоновую, салициловую кислоты и некоторые фенольные соединения [23,24].

В отличие от животных растения не имеют специальных органов, синтезирующих гормоны. Вместе с тем отмечается бо́льшая насыщенность гормонами некоторых их органов по сравнению с другими. Например, ауксинами обогащены верхушечные меристемы стебля и апикальная часть корня [25]: абсцизины обычно действуют в точке синтеза, распространяясь лишь на небольшое расстояние, а этилен транспортируется только в виде предшественника [26].

Фитогормоны обладают широким спектром действия и осуществляют координацию между отдельными клетками и тканями растений. Они регулируют многие процессы жизнедеятельности растений: прорастание семян, рост, дифференциацию тканей и органов, цветение и созревание плодов. Образуясь в одном органе (или его части) растения, фитогормоны обычно транспортируются в другой орган (или его часть). Экзогенные фитогормоны проникают в растения достаточно равномерно, а эндоген ные локализуются в отдельных депо клеток. Поэтому гормональная "подкормка" растений извне не заменяет естественный синтез фитогормонов и способна помочь растениям только в определенных условиях, в связи с чем необходимо развитие управляемого процесса синтеза фитогормонов.

Фитогормональное регуляторное воздействие на рост и развитие растений достигается двумя путями: изменением дозы фитогормона и вза имодействием фитогормонов. В зависимости от концентрации фитогормона его действие на один и тот же процесс может изменяться от стимуляции до ингибирования. Кроме того, изменение его концентрации может привести и к изменению характера действия фитогормона и физиологического ответа [27].

Согласно современным представлениям регуляторное воздействие фитогормонов обусловлено тем, что они регулируют экспрессию генов в растении [28], при этом действуют на разных уровнях. Фитогормоны взаимодействуют в растительной клетке с белками-рецепторами и образуют своеобразный гормон-рецепторный комплекс, который далее проникает в ядро и вступает в контакт с хроматином. Рецепторы располагаются как на мембранах, так и в цитозоле. Поэтому один и тот же гормон может связываться с разными рецепторами, тем самым вызывая различные ответные физиологические реакции. Именно это interaction of phytohormones. Depending on the concentration of phytohormone, its effect on the same process can vary from stimulation to inhibition. Furthermore, a change in its concentration can lead to a change in the nature of the action of the phytohormone and physiological response [27].

According to modern concepts, the regulatory effect of phytohormones is due to the fact that they regulate gene expression in a plant [28], and at the same time they act at different levels. Phytohormones interact in the plant cell with receptor proteins and form a kind of hormonereceptor complex, which then penetrates the nucleus and comes into contact with chromatin. Receptors are located both on membranes and in the cytosol. Therefore, the same hormone can bind to different receptors, thereby causing different physiological responses. This is one of the reasons for the multilevel action of phytohormones. At the first level, the direct interaction of phytohormone with DNA changes the structural state of chromatin and thereby affects its matrix activity. The second possible level of phytohormone effect is associated with the implementation of hereditary information through their influence on specific RNA polymerase enzymes that can "recognize" certain genes and synthesize giant molecules - precursors of messenger RNA (pre-mRNA). At the same time, phytohormones can regulate the life time of mRNA, as well as the process of its entry into the cytoplasm. Phytohormonal regulation of gene expression is possible at the level of translation - protein synthesis in ribosomes.

Thus, phytohormones not only regulate cell growth and development, but also are supra-cellular regulatory mechanisms. Methods of regulation can be different: some phytohormones can lower the expression of the target gene, others, on the contrary, can activate it. Therefore, competitive relationships arise between phytohormones. The formation and accumulation of one hormone instead of another, leads to a change in the nature of growth processes. Furthermore, one hormone can stimulate or inhibit the synthesis of another hormone.

Along with the differential effect on genome activity, the influence of phytohormones on the regulation of cell membrane permeability is of great importance. As a result of the association of the phytohormone with the membrane receptor, the membrane potential changes, which leads to the activation of the functional system of the cell, 
является одной из причин многоуровневости действия фитогормонов. На первом уровне пря мое взаимодействие фитогормона с ДНК изме няет структурное состояние хроматина и тем самым влияет на его матричную активность. Второй возможный уровень воздействия фитогормонов связан с реализацией наследственной информации посредством их влияния на специфические ферменты РНК-полимеразы, способные узнавать определенные гены и синтезировать гигантские молекулы - предшественники информационной РНК (пре-иРНК). При этом фитогормоны могут регулировать время жизни мРНК, а также процесс ее поступления в цито плазму. Фитогормональная регуляция экспрессии генов возможна и на уровне трансляции синтеза белка в рибосомах.

Таким образом, фитогормоны не только регулируют рост и развитие клетки, но и являются надклеточными механизмами регуляции. Способы регуляции могут быть разными: одни фито гормоны могут понизить экспрессию целевого гена, другие, наоборот, могут его активировать. Поэтому между фитогормонами возникают кон курентные отношения. Образование и накопле ние одного гормона вместо другого приводит к изменению характера ростовых процессов. Кроме того, один гормон может стимулировать или ингибировать синтез другого гормона.

Наряду с дифференциальным действием на активность генома большое значение имеет влияние фитогормонов на регуляцию проница емости клеточных мембран. В результате связи фитогормона с рецептором мембраны изменяется мембранный потенциал, что приводит к активации функциональной системы клетки, вследствие чего происходит активация / инактивация соответствующих генов [26, 29, 30].

Гормональная система на каждом этапе развития растения характеризуется определенным статусом: состоянием фитогормональной системы в онтогенезе растения, уровнем кон центрации и соотношением между фитогормо нами в процессах их образования, передвиже ния, использования и инактивации в ответ на внешние воздействия [31]. Гормональный статус может быть изменен воздействием экзогенных факторов (различных технологических приемов, изменяющих условия роста). Исходя из этого, можно предположить, что свет является одним из значимых факторов изменения гормональ ного статуса растений, а следовательно, и регу ляции их онтогенеза. as a result of which the corresponding genes are activated / inactivated [26, 29, 30].

The hormonal system at each stage of plant development is characterized by a certain status: the state of the phytohormonal system in plant ontogenesis, the concentration level and the ratio between phytohormones in the processes of their formation, movement, use and inactivation in response to external influences [31]. Hormonal status can be changed by the influence of exogenous factors (various technological methods that change the growth conditions). Based on the above, it can be assumed that light is one of the significant factors in the change in the hormonal status of plants, and, consequently, in the regulation of their ontogenesis.

\section{EXPERIMENTAL RESULTS OF THE STUDY OF LIGHT CONTROL OF PLANT MORPHOGENESIS}

A number of previous studies using monochromators and special spectral filters made it possible to study in detail the effect of the qualitative composition of light on plant development [32]. However, these studies still have not given an unambiguous answer to the question: how does light control the genome of plants and how to create an optimal lighting mode by combining the spectral components of radiation and their intensity to maximize the genetic potential of plants? Apparently, this was largely due to the absence of broadband radiation sources with a controlled spectral composition. One of the ways to obtain broadband light radiation is the joint use of various semiconductor LEDs in one lighting device. Modern LEDs cover an extremely wide range of radiation spectra - from ultraviolet to infrared [33]. Thus, combining a set of different LEDs, you can create multispectral controlled light sources that allow you to get light of any intensity and with almost any spectral composition. Fig. 2 shows the spectral characteristics of a controlled multielement matrix LED light source described in [34, 35]. This light source allows for a given program to change the intensity, spectral composition and duration of the light flux.

The authors of [36] studies the influence of the spectral composition and intensity of broadband light radiation on the growth and development of plants using a multi-element matrix LED light source, the emission spectrum of which varied in the wavelength range of 440-660 nm and could be emitted both in mono and polychromatic modes, and close in spectral composition to the solar 
4. ЭКСПЕРИМЕНТАЛЬНЫЕ РЕЗУЛЬТАТЫ ИЗУЧЕНИЯ СВЕТОВОГО УПРАВЛЕНИЯ МОРФОГЕНЕЗОМ РАСТЕНИЙ

Множество ранее выполненных исследований с использованием монохроматоров и специальных спектральных фильтров позволило детально изучить влияние качественного состава света на развитие растений [32]. Однако эти исследования до сих пор не дали однозначного ответа на вопрос: каким образом свет управляет геномом растений и как комбинацией спектральных компонент излучения и их интенсивности создать оптимальный режим освещения, чтобы максимально раскрыть генетический потенциал растений? По-видимому, в значительной мере это было обусловлено отсутствием широкополосных источников излучения с управляемым спектральным составом. Одним из способов получения широкополосного светового излучения является совместное использование в одном осветительном приборе различных полупроводниковых светодиодов. Современные светодиоды перекрывают чрезвычайно широкий диапазон спектров излучения - от ультрафиолетового до инфракрасного [33]. Таким образом, комбинируя набор разных светодиодов, можно создать мультиспектральные управляемые источники света, позволяющие получить свет любой интенсивности и с практически любым спектральным составом. На рис. 2 приведены спектральные характеристики управляемого многоэлементного матричного светодиодного источника света, описанного в работах [34, 35]. Данный источник света позволяет по заданной программе изменять интенсивность, спектральный состав и длительность светового потока.

В работе [36] изучено влияние спектрального состава и интенсивности широкополосного светового излучения на рост и развитие растений с использованием многоэлементного матричного светодиодного источника света, спектр излучения которого варьировался в диапазоне длин волн 440-660 нм и мог излучаться как в моно- и полихроматическом режимах, так и в близком по спектральному составу к спектру излучения Солнца (рис. 2). Эксперименты проводили на растениях - регенерантах картофеля Solanum tuberosum L., оздоровленных методом апикальной меристемы и культивируемых в условиях in vitro. Для контроля использовали растения, выращенные под люминесцентными лампами (LFW). Результаты экспериментов, иллюстрирующие динамику развития растений при воздействии разных спектров излучения, представлены на рис. 3 [37].
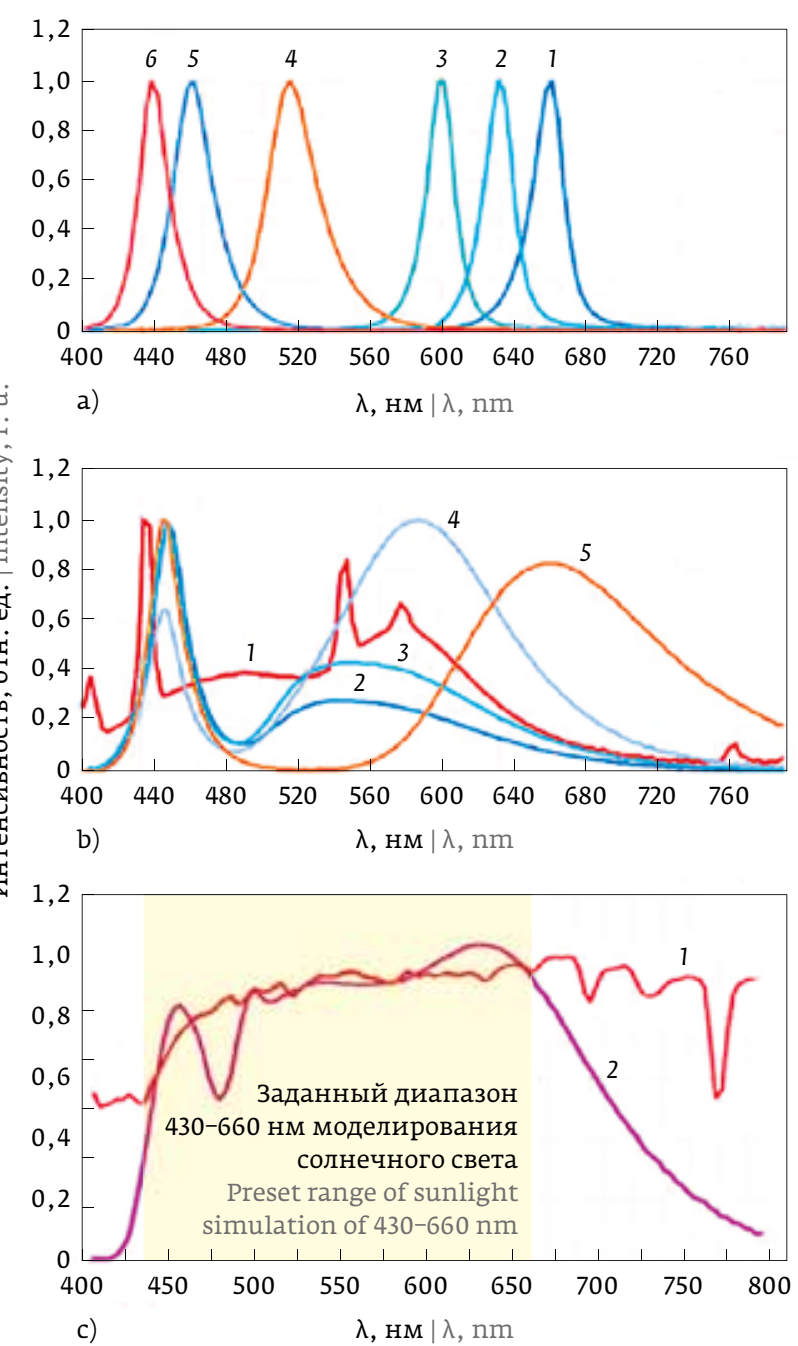

Puc. 2. Примеры спектров излучения, создаваемых многоэлементным матричным светодиодным источником света: $а$ - монохроматический спектр: 1 - красный $(R), 2$ - глубокий красный (DR), 3 - желтый (Y), 4 - зеленый (G), 5 - голубой (B), b - глубокий голубой (RB); bспектры излучения: 1 - пюминесцентная пампа белого cвета (LFW), 2-5 - полихроматический спектр матричного многоэлементного LED: 2 - холодный белый (CW), 3 - белый $(W), 4$ - теплый белый (WW), 5 - полный спектр (FS); с - спектр излучения Солнца (S) - 1, полный спектр многоэлементного матричного LED (SS) - 2

Fig. 2. Examples of radiation spectra generated by a multielement matrix LED light source: a-monochromatic spectrum: 1 - red (R), 2 - deep red (DR), 3 - yellow $(Y)$, 4 - green (G), 5 - blue (B), 6 - deep blue (RB); b-emission spectra: 1 - white light fluorescent lamp (LFW), 2-5 - polychromatic spectrum of a matrix multi-element LED: 2 - cold white (CW), 3-white (W), 4- warm white (WW), 5- full spectrum (FS); c - solar radiation spectrum (S) - 1, full spectrum of multi-element matrix LED (SS) - 2 

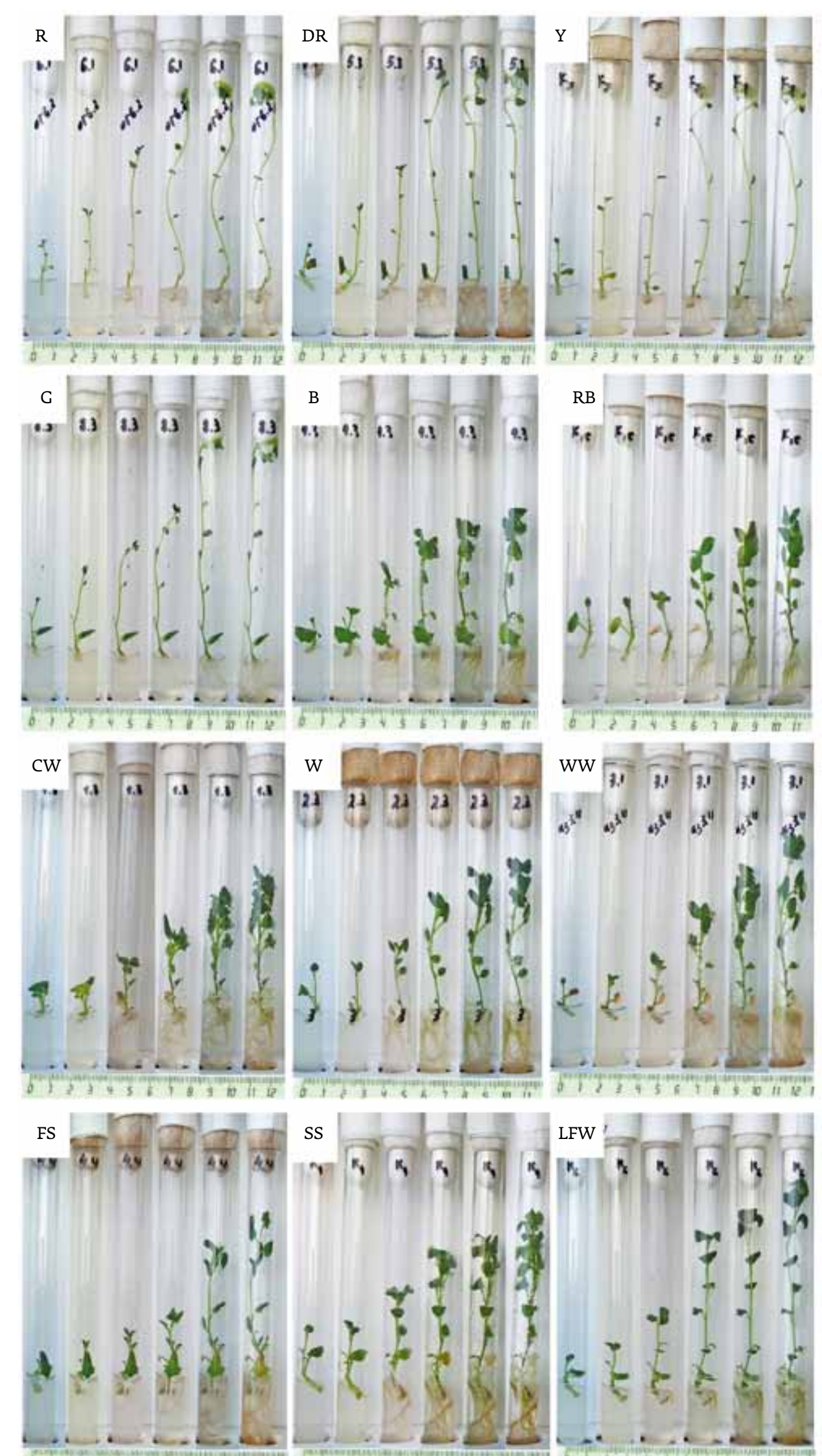

Puc. 3. Микроклональные растения картофеля, выращенные in vitro при облучении разными спектрами излучения, создаваемого управляемыми матричными LED-источниками света (интервал фиксации результатов эксперимента-7дней) Fig. 3. Microclonal potato plants grown in vitro when illuminated with different spectra of radiation generated by controlled matrix LED light sources (interval of recoding the results of the experiment is 7 days 
Опыты показали, что растения, выросшие на синем свету (B, RB), приземисты, а на красном (R, DR) - вытянуты. Листья первых имеют нор мальные размеры, вторых - недоразвиты и непра вильной формы. Данные проявления онтогенеза обусловлены тем, что красные лучи спектра стиму лируют фазу растяжения клеток, а сине-фиолето вые - фазу дифференциации. Растения, выросшие под желтым и зеленым излучением $(\mathrm{Y}, \mathrm{G})$, демон стрируют вытянутость и слабое развитие листвы, т.е. монохроматический желтый и зеленый свет способствует быстрому росту в длину (при этом формируются хрупкие и тонкие растения), но это не приводит к накоплению достаточной биомассы. В целом для растений, культивируемых при монохроматическом свете (кроме синего и глубокого синего), отмечена максимальная высота стебля, в 1,5 раза превышающая аналогичный показатель у контрольной группы растений, выращиваемых под люминесцентной лампой. Наибольшее увеличение длины стебля у данных групп растений происходит за счет вытягивания междоузлий. Полученные результаты, по-видимому, связаны со спектральной зависимостью монохроматического светового стимулирования гормонов роста растений: ауксинов и цитокининов.

Переход к полихроматическому и широкополосному излучению (CW, W, WW, FS и SS) демонстрирует явное отличие от монохроматического освещения, которое проявляется в более интенсивном развитии листвы и корневой системы растений. В то же время высота растений, культивируемых при полихроматическом свете, в 0,6 раза меньше, чем в контроле (люминесцентная лампа - LFW)). Наибольшая длина и ширина листьев наблюдаются у растений, выращиваемых при глубоком синем (RB) и холодном белом свете (CW). Максимальная масса надземной части растений отмечена у экземпляров, выращенных при полихроматическом свете ( $\mathrm{CW}$ и $\mathrm{W})$. Это свидетельствует об эффективности полихроматического светового излучения, имеющего парные спектральные максимумы на длинах волн 446,8 и 546,9 нм (CW), 446,8 и 550,2 нм (W), что стимулирует процесс образования хлорофиллов и кратоиноидов и влияет на увеличение массы растений.

Очень часто универсальность и эффективность не совпадают. Исследования на ценозах показали, что у растений разных видов наблюдаются различные требования к оптимальному сочетанию спектральных и энергетических характеристик светового режима [38]. Как отмечалось выше, основную роль в регуляции морфогенетических radiation spectrum (Fig. 2). The experiments were carried out on plants - regenerants of the potato Solanum tuberosum L., healed by the apical meristem method and cultivated in vitro. For control, plants grown under fluorescent lamps (LFW) were used. The experimental results illustrating the dynamics of plant development under the influence of different radiation spectra are presented in Fig. 3 [37].

The experiments showed that plants grown in blue light $(B, R B)$ are low-growing, and in red (R, DR) elongated. The leaves of the former are of normal size, the latter are underdeveloped and irregular in shape. These manifestations of ontogenesis are due to the fact that the red rays of the spectrum stimulate the cell stretching phase, and the blueviolet rays stimulate the differentiation phase. Plants grown under yellow and green radiation $(Y, G)$ show elongation and poor development of foliage, i.e. monochromatic yellow and green light promotes rapid growth in length (brittle and thin plants are formed), but this does not lead to the accumulation of sufficient biomass. In general, for plants cultivated under monochromatic light (except for blue and deep blue), the maximum stem height was 1.5 times higher than that of the control group of plants grown under a fluorescent lamp. The greatest increase in stem length in these plant groups occurs due to the extension of internodes. The results obtained are apparently associated with the spectral dependence of monochromatic light stimulation of asthenia growth hormones: auxins and cytokinins.

The transition to polychromatic and broadband radiation ( $\mathrm{CW}, \mathrm{W}, \mathrm{WW}, \mathrm{FS}$ and $\mathrm{SS}$ ) demonstrates a clear difference from monochromatic lighting, which manifests itself in a more intensive development of foliage and root system of plants. At the same time, the height of plants cultivated in polychromatic light is 0.6 times less than in control (fluorescent lamp - LFW). The greatest length and width of leaves are observed in plants grown in deep blue (RB) and cold white light $(\mathrm{CW})$. The maximum mass of the aerial parts of plants was observed in specimens grown in polychromatic light (CW and $W)$. This indicates the effectiveness of polychromatic light radiation having paired spectral maxima at wavelengths of 446.8 and $546.9 \mathrm{~nm}(\mathrm{CW}), 446.8$ and $550.2 \mathrm{~nm}(\mathrm{~W})$, which stimulates the formation of chlorophylls and cratinoids, and affects the increase mass of plants.

Very often, versatility and effectiveness do not match. Studies on cenoses have shown that different types of plants exhibit different 
процессов у растений выполняют фоторецепторы: фитохромы, криптохромы и фототропин, управляющие фитогормонами клеток растений, синтез и воздействие на которые активированных светом фоторецепторных белков либо не исследованы вообще, либо изучены недостаточно. В частности, известно, что красный и синий свет изменяет содержание отдельных групп фитогормонов, что может проявиться в специфичности действия спектра излучения на морфогенез растений.

Были проведены эксперименты по выращиванию in vitro микроклональных растений картофеля Solanum tuberosum L. при освещении двухкомпонентным излучением с длинами волн 460 и 660 нм, которые попадают в максимум поглощения хлорофилла $b$, a также при освещении широкополосным светодиодным излучением (SS) в диапазоне длин волн от 440 до 660 нм. В последнем случае SS-спектр излучения позволяет не только возбудить хлорофилл а и b, но и активировать практически все фоторецепторные белки растений. На рис. 4 приведены фотографии динамики развития микроклональных растений в сравнении с кон трольным освещением люминесцентной лампой белого света. Результаты экспериментов показали, что использование SS-источника излучения позволяет добиться увеличения биомассы растений на $30 \%$ в сравнении с двухволновым облучением и увеличения биомассы на 17\% по отноше- requirements for the optimal combination of spectral and energy characteristics of the light regime [38]. As noted above, the main role in the regulation of morphogenetic processes in plants is played by photoreceptors: phytochromes, cryptochromes and phototropin, which control plant cell phytohormones, the synthesis of which and exposure to light-activated photoreceptor proteins are either not studied at all or are not well understood. In particular, it is known that red and blue light changes the content of individual groups of phytohormones, which can manifest itself in the specificity of the action of the radiation spectrum on plant morphogenesis.

In vitro experiments were carried out on growing microclonal potato plants Solanum tuberosum $L$. when lighted with two-component radiation with wavelengths of 460 and $660 \mathrm{~nm}$, which fall at the maximum absorption of chlorophyll $b$, as well as when lighted with broadband LED radiation (SS) in the wavelength range from 440 up to $660 \mathrm{~nm}$. In the latter case, the SS radiation spectrum allows not only to excite chlorophyll a and b, but also to activate almost all plant photoreceptor proteins. Fig. 4 shows photographs of the dynamics of the development of microclonal plants in comparison with the control lighting with a white light fluorescent lamp. The experimental results showed that the use of SS-radiation source allows to achieve

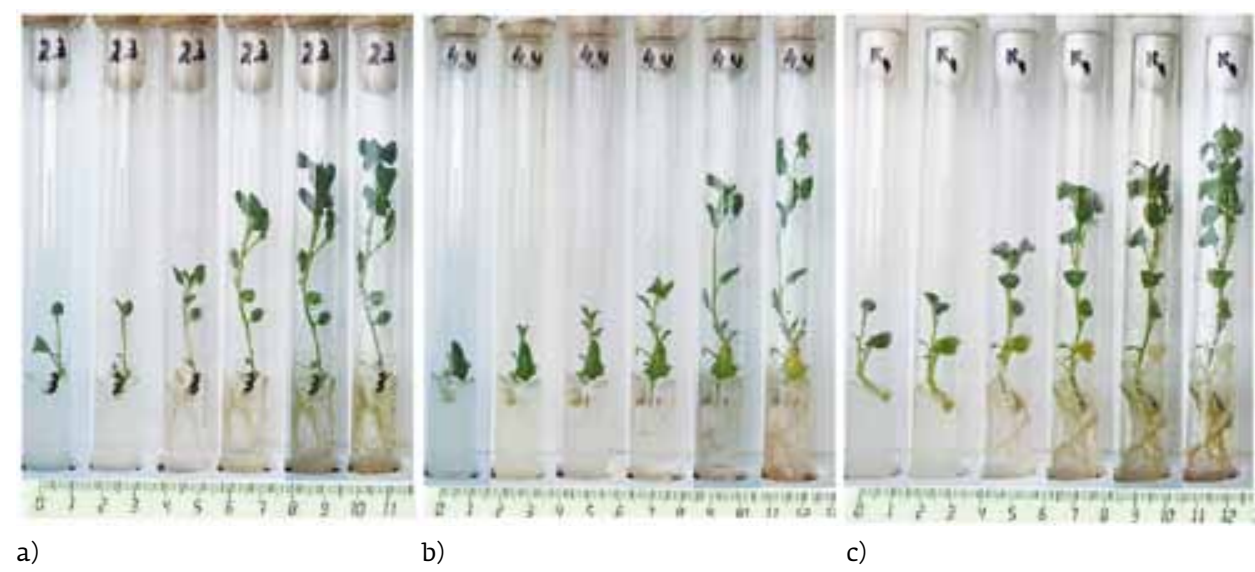

Puc. 4. Микроклональные растения картофеля, выращенные in vitro при облучении: $а$ - люминесцентной лампой белого света (LFW), б - двухспектральным LED-источником с максимумами на длинах волн 460 и 660 нм, в-управляемым SS-многокомпонентным матричным LED-источником с разными спектрами излучения на длинах волн 440-660 нм. Интервал фиксации развития растений - 7 дней

Fig. 4. Microclonal potato plants grown in vitro upon illumination with: a - a white light fluorescent lamp (LFW), $b$ - a two-spectral LED source with maxima at wavelengths of 460 and $660 \mathrm{~nm}, c$ - a controlled SS-multicomponent matrix LED source with different emission spectra at wavelengths of 440-660 $\mathrm{nm}$. The interval of recording plant development is 7 days 
нию к контрольному освещению. Таким образом, для обеспечения максимальной продуктивности растений целесообразно использование широкополосного светового излучения.

Существующие источники искусственного света, за редким исключением, не могут воспроизводить солнечный спектр в диапазоне фотосинтетически активной радиации или генерируют похожий спектр, но с пиковыми выбросами на ряде отдельных частот (рис. 1), что не позволяет добиться их максимальной эффективности. Поэтому SS-многокомпонентный матричный LED источник излучения представляет значительный интерес для повышения урожайности сельскохозяйственных культур. В то же время наряду с подбором спектрального состава излучения необходимо обращать внимание и на энергетическую компоненту излучения. Исследования, выполненные in vitro с растениями - регенерантами картофеля $S$. tuberosum сортов "Рождественский" и "Снегирь", а также Стевии медовой (Stevia rebaudiana), показали наличие оптимальной интенсивности широполосного освещения растений, при которых достигается их максимальный отклик [39, 40].

На рис. 5 приведены фотографии, иллюстрирующие эффективность процесса развития Стевии медовой при разном уровне интенсивности ее освещения широкополосным источником излучения спектра SS.

Воспринимая световые сигналы, фоторецепторы инициируют внутриклеточные сигнальные пути и тем самым регулируют развитие растений на протяжении всего жизненного цикла. Сигналом для запуска морфогенеза растений служит изменение соотношения фитогормонов цитокининов и ауксинов, которые являются регуляторами не только an increase in plant biomass by $30 \%$ compared with two-wave irradiation and an increase in biomass by $17 \%$ in relation to control lighting. Thus, to ensure maximum plant productivity, it is advisable to use broadband light radiation.

The existing artificial light sources, with rare exceptions, cannot reproduce the solar spectrum in the range of photosynthetically active radiation or generate a similar spectrum, but with peak emissions at a number of separate frequencies (Fig. 1), which does not allow achieving their maximum efficiency. Therefore, the SS-multicomponent matrix LED radiation source is of significant interest for increasing crop yields. At the same time, along with the selection of the spectral composition of the radiation, it is necessary to pay attention to the energy component of the radiation. In vitro studies with regenerated plants of $S$. tuberosum potatoes of the Rozhdestvensky and Bullfinch varieties, as well as of Stevia rebaudiana, showed the presence of an optimal intensity of broadband lighting of asthenia, at which their maximum response is achieved [39, 40].

Fig. 5 shows photographs illustrating the effectiveness of the development process of Stevia rebaudiana at different levels of its intensity of lighting by a broadband radiation source of the SS spectrum.

Perceiving light signals, photoreceptors initiate intracellular signaling pathways and thereby regulate plant development throughout the entire life cycle. A signal for starting plant morphogenesis is a change in the ratio of phytohormones of cytokinins and auxins, which are regulators of not only growth, but also differentiation of cellular structures. The interaction of plant hormones

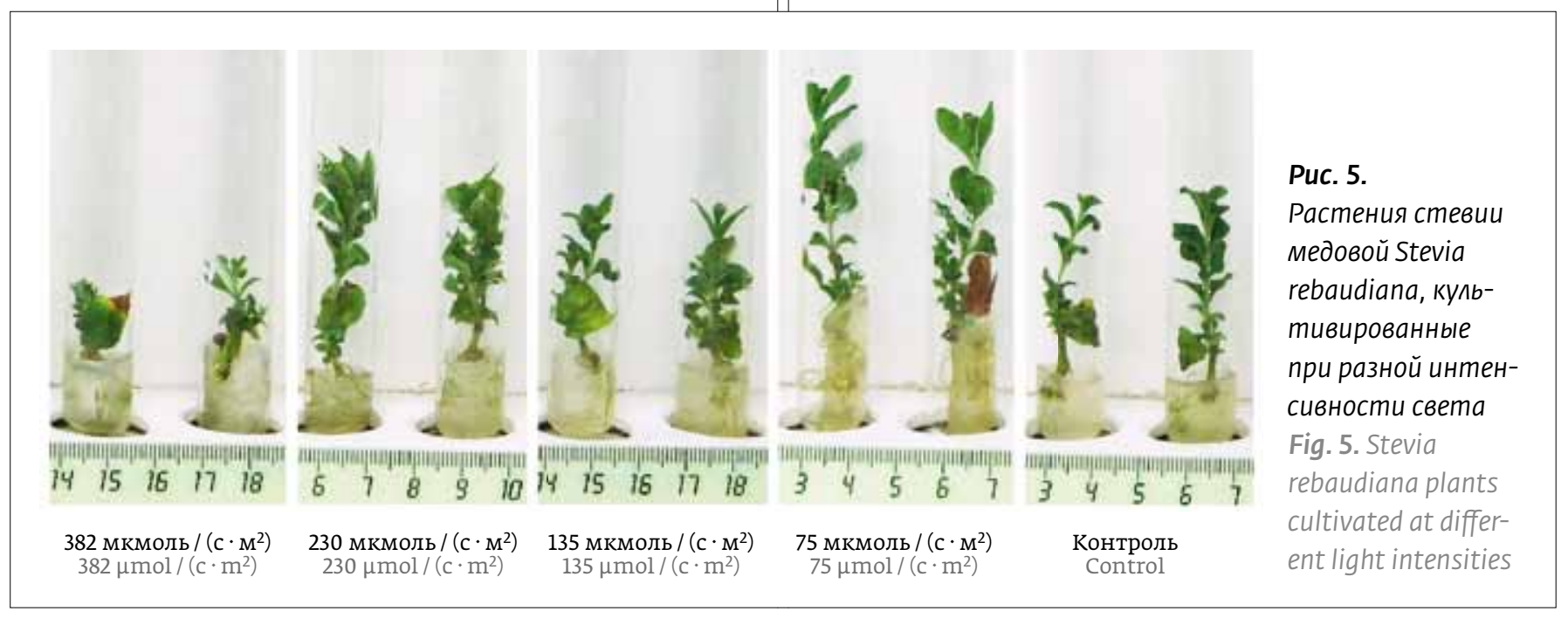


роста, но и дифференцировки клеточных структур. Взаимодействие гормонов растений может наблюдаться в формах синергизма и антагонизма. Синергическое действие связано с взаимным усилением действия гормонов на какой-либо процесс. Так, в частности, регенерация побегов из каллуса активизируется под действием цитокининов в присутствии ауксинов. Как правило, существует несколько путей, по которым может пойти развитие каллусной клетки. Поскольку основную роль в регуляции морфогенетических процессов светом выполняют фоторецепторы, то в каллусной структуре под воздействием света происходит синтез фитогормонов, который активируется различным спектром излучения через фоторецепторные белки.

В культуре каллусных тканей под морфогенезом понимают возникновение организованных структур из неорганизованной массы клеток. В работе [34] исследовалось влияние спектра облучения на развитие дифференцированных зон в каллусной массе клеточной культуры риса сорта "Долинный". На рис. 6 приведены фотографии, иллюстрирующие понедельную динамику развития каллусной культуры в in vitro.

Было установлено, что для каждого спектра излучения существует оптимальная интенсивность излучения, при которой наблюдается максимальная скорость развития каллусной культуры. В таблице 1 приведены результаты наблюдений временного процесса развития каллусной клеточной культуры риса сорта "Долинный" под воздействием различных спектров излучения, которые позволяют проследить динамику влияния регулируемого различным спектром излучения фоторецепторного отклика на взаимодействия гормонов ауксинов и цитокининов. Известно, что ауксины действуют на рост клеток двухфазно в зависимости от кон- $^{-}$ центрации: при низких дозах ускоряют, а при более высоких тормозят процессы роста. В стерильных тканевых культурах увеличение содержания цитокининов вызывает дифференцировку клеток в зависимости от концентрации гормона.

В частности, под действием фитогормона цитокинина в растениях синтезируется хлорофилл. Как видно, присутствие значительной части синего can be observed in the forms of synergism and antagonism. A synergistic effect is associated with a mutual increase in the action of hormones on any process. So, in particular, the regeneration of shoots from callus is activated by the action of cytokinins in the presence of auxins. As a rule, there are several ways in which callus cell development can go. Since photoreceptors play the main role in the regulation of morphogenetic processes by light, phytohormones are synthesized in the callus structure under the influence of light, which is activated by a different radiation spectrum through photoreceptor proteins.

In the culture of callus tissues, morphogenesis is understood as the emergence of organized structures from an unorganized mass of cells. In [34], the influence of the irradiation spectrum on the development of differentiated zones in the callus mass of the cell culture of rice of the Valley variety was studied. Fig. 6 shows photographs illustrating the week-wise dynamics of the development of callus culture in vitro.

It was found that for each radiation spectrum there is an optimal radiation intensity at which the maximum rate of development of the callus culture is observed. The table shows the results of observations of the temporary process of development of the callus cell culture of rice of the Valley variety under the influence of various radiation spectra, which allow us to trace the dynamics of the effect of the photoreceptor response regulated by various radiation spectra on the interactions of auxin and cytokinin hormones. It is known that auxins act
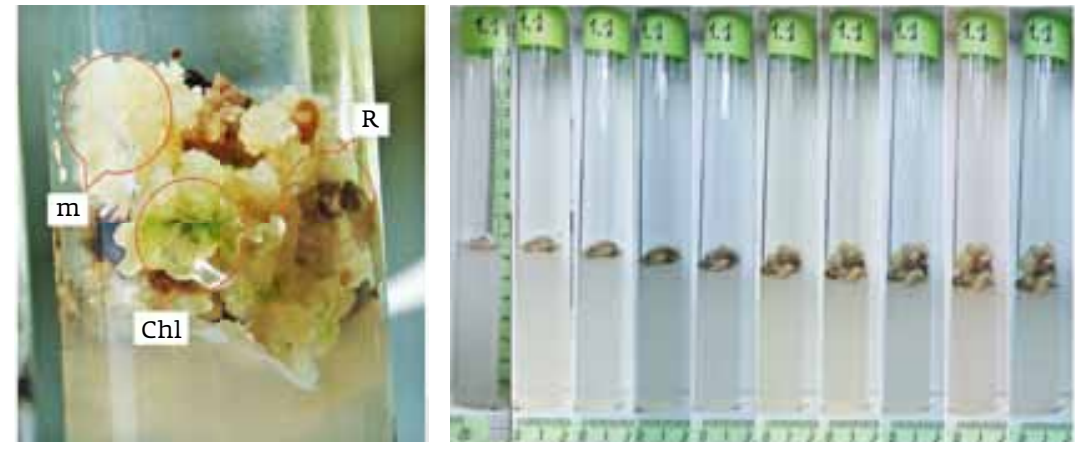

Puc. 6. Каплусная масса (m) клеточной культуры риса сорта "Долинный» (a) с включениями зеленой (ChI) и коричневой (R) зон, а также понедельная динамика развития культуры in vitro (6)

Fig. 6. Callus mass ( $m$ ) of the cell culture of rice of Valley variety (a) with inclusions of the green (Chl) and brown (R) zones, as well as the weekly dynamics of the in vitro culture development (b) 
света с небольшим содержанием красного в полихроматическом излучении LFW и CW (спектральный состав излучения показан на рис. 2) приводит к росту зеленой (хлорофилльной) массы, что, по-видимому, обусловлено повышением концентрации цитокининов по отношению к ауксинам. Уменьшение или отсутствие доли синего света в спектре излучения тормозит образование хлорофилльной массы, тогда как повышение доли крас- on the growth of cells in two phases, depending on the concentration: they accelerate at low doses and inhibit growth processes at higher doses. In sterile tissue cultures, an increase in the content of cytokinins causes differentiation of cells depending on the concentration of the hormone.

In particular, under the action of the phytohormone cytokinin, chlorophyll is synthesized in plants. As can be seen, the presence of a

Таблица 1. Динамика роста зеленой и коричневой зон, а также каллусной массы клеточной культуры риса сорта "Долинный" под воздействием различных спектров излучения.

Table. The growth dynamics of the green and brown zones, as well as the callus mass of the cell culture of rice of the valley variety under the influence of various radiation spectra.

\begin{tabular}{|c|c|c|c|c|c|c|c|c|c|c|}
\hline \multirow{2}{*}{$\begin{array}{c}\text { День } \\
\text { наблюдения } \\
\text { Observation } \\
\text { day }\end{array}$} & \multicolumn{10}{|c|}{$\begin{array}{l}\text { Спектр излучения } \\
\text { Emission spectrum }\end{array}$} \\
\hline & LFW & $\mathrm{CW}$ & W & WW & DR & $\mathrm{R}$ & $Y$ & $G$ & B & $\mathrm{RB}$ \\
\hline 42 & $\begin{array}{l}+ \\
- \\
-\end{array}$ & $\begin{array}{l}+ \\
- \\
-\end{array}$ & $\begin{array}{l}+ \\
- \\
-\end{array}$ & $\begin{array}{l}+ \\
- \\
-\end{array}$ & $\begin{array}{l}- \\
- \\
m\end{array}$ & $\begin{array}{l}- \\
- \\
\mathrm{m}\end{array}$ & $\begin{array}{l}- \\
- \\
\mathrm{m}\end{array}$ & $\begin{array}{l}- \\
- \\
m\end{array}$ & $\begin{array}{l}- \\
- \\
\mathrm{m}\end{array}$ & $\begin{array}{l}+ \\
- \\
-\end{array}$ \\
\hline 49 & $\begin{array}{c}++ \\
- \\
-\end{array}$ & $\begin{array}{l}+ \\
- \\
-\end{array}$ & $\begin{array}{l}+ \\
- \\
-\end{array}$ & $\begin{array}{l}+ \\
- \\
-\end{array}$ & $\begin{array}{l}- \\
- \\
m\end{array}$ & $\begin{array}{l}- \\
- \\
\mathrm{m}\end{array}$ & $\begin{array}{l}- \\
- \\
\mathrm{m}\end{array}$ & $\begin{array}{l}- \\
- \\
\mathrm{m}\end{array}$ & $\begin{array}{c}++ \\
- \\
-\end{array}$ & $\begin{array}{l}++ \\
- \\
-\end{array}$ \\
\hline 56 & $\begin{array}{c}++ \\
- \\
-\end{array}$ & $\begin{array}{l}+ \\
- \\
-\end{array}$ & $\begin{array}{l}+ \\
- \\
-\end{array}$ & $\begin{array}{l}+ \\
- \\
-\end{array}$ & $\begin{array}{l}- \\
- \\
m\end{array}$ & $\begin{array}{l}- \\
- \\
\mathrm{m}\end{array}$ & $\begin{array}{l}- \\
- \\
\mathrm{m}\end{array}$ & $\begin{array}{l}- \\
- \\
\mathrm{m}\end{array}$ & $\begin{array}{c}+++ \\
- \\
-\end{array}$ & $\begin{array}{l}++ \\
- \\
-\end{array}$ \\
\hline 63 & $\begin{array}{l}+++ \\
- \\
-\end{array}$ & $\begin{array}{l}+ \\
- \\
-\end{array}$ & $\begin{array}{l}+ \\
- \\
-\end{array}$ & $\begin{array}{l}+ \\
- \\
-\end{array}$ & $\begin{array}{l}- \\
- \\
m\end{array}$ & $\begin{array}{l}- \\
- \\
\mathrm{m}\end{array}$ & $\begin{array}{l}- \\
- \\
\mathrm{m}\end{array}$ & $\begin{array}{l}- \\
- \\
\mathrm{m}\end{array}$ & $\begin{array}{c}+++ \\
- \\
-\end{array}$ & $\begin{array}{l}+ \\
- \\
\mathrm{m}\end{array}$ \\
\hline 70 & $\begin{array}{c}+++ \\
- \\
-\end{array}$ & $\begin{array}{c}+++ \\
- \\
-\end{array}$ & $\begin{array}{l}+ \\
- \\
-\end{array}$ & $\begin{array}{l}+ \\
\mathrm{R} \\
-\end{array}$ & $\begin{array}{l}- \\
- \\
m\end{array}$ & $\begin{array}{l}- \\
- \\
\mathrm{m}\end{array}$ & $\begin{array}{l}- \\
- \\
\mathrm{m}\end{array}$ & $\begin{array}{l}- \\
- \\
\mathrm{m}\end{array}$ & $\begin{array}{c}++ \\
\mathrm{R} \\
-\end{array}$ & $\begin{array}{l}+ \\
- \\
\mathrm{m}\end{array}$ \\
\hline 77 & $\begin{array}{c}+++ \\
- \\
-\end{array}$ & $\begin{array}{c}+++ \\
- \\
-\end{array}$ & $\begin{array}{l}- \\
- \\
-\end{array}$ & $\begin{array}{l}+ \\
\mathrm{R} \\
-\end{array}$ & $\begin{array}{l}- \\
\mathrm{R} \\
\mathrm{m}\end{array}$ & $\begin{array}{l}- \\
\mathrm{R} \\
\mathrm{m}\end{array}$ & $\begin{array}{l}- \\
- \\
\mathrm{m}\end{array}$ & $\begin{array}{l}- \\
- \\
\mathrm{m}\end{array}$ & $\begin{array}{l}+ \\
\mathrm{R} \\
\mathrm{m}\end{array}$ & $\begin{array}{l}- \\
- \\
\mathrm{m}\end{array}$ \\
\hline 84 & $\begin{array}{c}+++ \\
- \\
-\end{array}$ & $\begin{array}{c}++++ \\
- \\
-\end{array}$ & $\begin{array}{l}- \\
- \\
-\end{array}$ & $\begin{array}{c}++ \\
\mathrm{R} \\
-\end{array}$ & $\begin{array}{l}- \\
\mathrm{R} \\
\mathrm{m}\end{array}$ & $\begin{array}{l}- \\
\mathrm{R} \\
\mathrm{m}\end{array}$ & $\begin{array}{l}- \\
- \\
m\end{array}$ & $\begin{array}{l}- \\
- \\
m\end{array}$ & $\begin{array}{l}+ \\
\mathrm{R} \\
\mathrm{m}\end{array}$ & $\begin{array}{l}- \\
- \\
\mathrm{m}\end{array}$ \\
\hline 91 & $\begin{array}{c}+++ \\
- \\
-\end{array}$ & $\begin{array}{c}+++++ \\
- \\
-\end{array}$ & $\begin{array}{l}- \\
- \\
\mathrm{m}\end{array}$ & $\begin{array}{c}++ \\
\mathrm{R} \\
\mathrm{m}\end{array}$ & $\begin{array}{l}- \\
\mathrm{R} \\
\mathrm{m}\end{array}$ & $\begin{array}{l}- \\
\mathrm{R} \\
\mathrm{m}\end{array}$ & $\begin{array}{l}- \\
- \\
m\end{array}$ & $\begin{array}{l}- \\
- \\
\mathrm{m}\end{array}$ & $\begin{array}{l}- \\
\mathrm{R} \\
\mathrm{m}\end{array}$ & $\begin{array}{l}- \\
- \\
\mathrm{m}\end{array}$ \\
\hline 98 & $\begin{array}{c}+++ \\
\mathrm{R} \\
-\end{array}$ & $\begin{array}{c}+++++ \\
- \\
-\end{array}$ & $\begin{array}{l}- \\
- \\
\mathrm{m}\end{array}$ & $\begin{array}{c}++ \\
\mathrm{R} \\
\mathrm{m}\end{array}$ & $\begin{array}{l}- \\
- \\
m\end{array}$ & $\begin{array}{l}- \\
\mathrm{R} \\
-\end{array}$ & $\begin{array}{l}- \\
- \\
\mathrm{m}\end{array}$ & $\begin{array}{l}- \\
- \\
m\end{array}$ & $\begin{array}{l}- \\
\mathrm{R} \\
\mathrm{m}\end{array}$ & $\begin{array}{l}- \\
- \\
\mathrm{m}\end{array}$ \\
\hline 105 & $\begin{array}{c}+++ \\
\mathrm{R} \\
-\end{array}$ & $\begin{array}{c}+++++ \\
\mathrm{R} \\
\mathrm{m}\end{array}$ & $\begin{array}{l}- \\
- \\
-\end{array}$ & $\begin{array}{c}++ \\
\mathrm{R} \\
\mathrm{m}\end{array}$ & $\begin{array}{l}- \\
- \\
-\end{array}$ & $\begin{array}{l}- \\
\mathrm{R} \\
-\end{array}$ & $\begin{array}{l}- \\
- \\
m\end{array}$ & $\begin{array}{l}- \\
- \\
\mathrm{m}\end{array}$ & $\begin{array}{l}+ \\
\mathrm{R} \\
\mathrm{m}\end{array}$ & $\begin{array}{l}- \\
- \\
\mathrm{m}\end{array}$ \\
\hline
\end{tabular}

Примечание. +- увеличение объема хлорофилла, R - увеличение объема коричневой зоны, $\mathrm{m}$ - увеличение объема каллусной массы. Прочерк означает отсутствие роста.

Note: + - increase in the volume of chlorophyll, $\mathrm{R}$ - increase in the volume of the brown zone, $\mathrm{m}$ - increase in the volume of callus mass. A dash indicates "no growth". 
ной компоненты ведет к образованию коричневой (корневой) клеточной структуры и росту массы каллуса, что, видимо, обусловлено повышением концентрации ауксинов.

Таким образом, выявленный процесс регуля торного действия спектра излучения на ключевые этапы дифференцировки клеток каллуса, зависящие от соотношения гормонов ауксинов и цито кининов, образующихся под воздействием фото рецепторной системы в клеточной массе каллусов, дает основание говорить о необходимости дальнейшего развития фундаментальных исследований регуляторного действия света, которые должны послужить прогрессу в создании новых механиз мов эндогенной регуляции развития растений.

\section{ЗАКЛЮЧЕНИЕ}

В отличие от животных растения изначально должны реагировать на свет, чтобы жить. Для этого у них существует созданная природой фоторецепторная система. Поэтому свет для растений не только источник энергии, но и важный фактор окружающей среды, который контролирует различ ные пути передачи сигналов. Свет является одним из основных регуляторов развития растений и их метаболизма. Экспрессия генов у растений регулируется светом на многих уровнях. Уровень генного продукта может контролироваться путем регуля ции уровня транскрипции его гена или путем регу ляции трансляции его мРНК в белок [41].

На сегодня взаимосвязь между фоторецепторной системой растений и эндогенными программами их развития по-прежнему остается малоизучен ной. Хотя активация светом генетического аппарата биосинтеза белков уже не вызывает сомнений, следует подчеркнуть, что, по-видимому, подобный эффект представляет собой не начальный, а один из заключительных этапов действия фоторецепторных белков, а материальная природа сигнала, распространяющегося от фоторецептора к ядру клетки, остается невыясненной. Положение усложняется еще и тем, что оклики различных фоторецепторных белков в ряде случаев дублиру ются или имеют сходное действие.

Ответить на все эти вопросы необходимо, если человечество ставит своей задачей овладеть процессом фотоморфогенеза растений в целях повы шения эффективности производства сельскохозяйственных культур и наиболее полного раскрытия их генетического потенциала.

Работа выполнена при финансовой поддержке Министерства науки и высшего образования РФ, номер соглашения: 05.604.21.0229. significant part of blue light with a small red content in the polychromatic radiation of LFW and CW (the spectral composition of radiation is shown in Fig. 2) leads to an increase in the green (chlorophyll) mass, which is apparently due to an increase in the concentration of cytokinins with respect to auxins. A decrease or absence of the proportion of blue light in the emission spectrum inhibits the formation of chlorophyll mass, while an increase in the proportion of the red component leads to the formation of a brown (root) cell structure and an increase in callus mass, which is apparently due to an increase in the concentration of auxins.

Thus, the revealed process of the regulatory effect of the radiation spectrum on the key stages of callus cell differentiation, depending on the ratio of the hormones of auxins and cytokinins formed under the influence of the photoreceptor system in the cell mass of calluses, gives reason to talk about the need for further development of fundamental studies of the regulatory action of light, which should contribute to progress in creating new mechanisms of endogenous regulation of plant development.

\section{CONCLUSION}

Unlike animals, plants must initially respond to light in order to live. For this, they have a naturecreated photoreceptor system. Therefore, light for plants is not only a source of energy, but also an important environmental factor that controls various signal transmission paths. Light is one of the main regulators of plant development and their metabolism. Gene expression in plants is regulated by light at many levels. The level of a gene product can be controlled by regulating the level of transcription of its gene or by regulating the translation of its mRNA into protein [41].

As of today, the relationship between the plant photoreceptor system and endogenous programs of their development remains poorly studied. Although light activation of the genetic apparatus of protein biosynthesis is no longer in doubt, it should be emphasized that, apparently, this effect is not the initial, but one of the final stages of the action of photoreceptor proteins, and the material nature of the signal propagating from the photoreceptor to the cell nucleus remains obscure. such reactions that occur almost immediately after lighting.

It is necessary to answer all these questions if humanity sets out to master the process of plant photomorphogenesis in order to increase the efficiency of crop production and the fullest disclosure of their genetic potential. 


\section{ЛИТЕРАТУРА}

1. Головацкая И. Ф. Морфогенез растений и его регуляция. Часть 1: Фоторегуляция морфогенеза растений. // Изд-во: НИУ Томский ГУ, 2016 г - 172 с.

2. Протасова Н. Н. Светокультура как способ выявления потенциальной продуктивности растений // Физиология растений. 1987. Т. 34. № 4. С. 812-822.

3. Гречкин А. Н., Тарчевский И.А. Сигнальные системы клеток и геном. // Биоорганическая химия. 2000.-т.26. № 10, с. 779-781.

4. Беленький Е. Ф., Рискин И. В. Химия и технология пигментов. Изд. 4-е, пер. и доп. - Л.: 1974.-656 с.

5. Холл Д., Рао К. Фотосинтез: Пер. с англ. // М.: Мир, 1983. - 134 с

6. Бриттон Г. Биохимия природных пигментов. // М.: Мир, 1986. - 422 с

7. Воскресенская Н. П. Фотосинтез и спектральный состав света. // М.: Наука, 1965. - 309 C.

8. Холл Д., Рао К. Фотосинтез. // М.: Мир, 1983. - 134 с

9. Blankenship R. E. Molecular Mechanisms of Photosynthesis. // Blackwell Science, Oxford-Paris, 2002. - $321 \mathrm{p}$

10. Ладыгин Г., Ширшикова Г.Н.Современные представления о функциональной роли каротиноидов в хлоропластах эукариот. // Журнал общей биологии. 2006, т. 67, № 3, с. 163-189.

11. Конев С. В. Фотобиология. // Изд-во: Мн.: БГУ. 1979. - 385с

12. Макаренко О.А., Левицкий А. П. Физиологические функции флавоноидов в растениях. // Физиология и биохимия культурных растений. 2013, т. 45, № 2 , с. $100-112$.

13. Червяковский В.П., Курченко В.А., Костюк Е. М. Роль флавоноидов в биологических реакциях с преносом электронов. // Труды Белорусского государственного университета. Минск. 2009. т. 4, часть 1. - 19-с.

14. Тюреева Е. В., Дмитриева В.А., Войцеховская О. В. Хлорофилл Ь как источник сигналов, регулирующих развитие и продуктивность растений. // Сельскохозяйственная биология. 2017, т. 52, в. 5, с. 843-855.

15. Baier M., Dietz K. J. Chloroplasts as source and target of cellular redox regulation: A discussion on chloroplast redox signals in the context of plant physiology. // Journal of Experimental Botany. 2005. v. 56, No. 416, p. 1449-1462.

16. Folta K. M., Childers K. S. Light as a Growth Regulator: Controlling Plant Biology with Narrow-bandwidth Solid-state Lighting Systems. // Hortscience.2008, v. 43,
This work was financially supported by the Ministry of Science and Higher Education of the Russian Federation, agreement number: 05.604.21.0229.

\section{REFERENCE}

1. Golovackaya I. F. Morfogenez rastenij i ego regulyaciya. CHast' l: Fotoregulyaciya morfogeneza rastenij. // Izd-vo: NIU Tomskij CU, $2016 \mathrm{~g}$ - 172 s

2. Protasova N.N. Svetokul'tura kak sposob vyyavleniya potencial'noj produktivnosti rastenij // Fiziologiva rastenij. 1987. T. 34. № 4. S. 812-822.

3. Grechkin A. N., Tarchevskij I.A. Signal'nye sistemy kletok i genom. // Bioorganicheskaya himiya. 2000.-t.26. № 10, s.779-781.

4. Belen'kij E. F., Riskin I.V. Himiya i tekhnologiya pigmentov. Izd. 4-e, per. i dop. - L.: 1974.-656s.

5. Holl D., Rao K. Fotosintez: Per. s angl. // M.: Mir, 1983. - 134 C.

6. Britton G. Biohimiya prirodnyh pigmentov. // M.: Mir, 1986. $-422 \mathrm{~s}$

7. Voskresenskaya N.P. Fotosintez i spektral'nyj sostav sveta. // M.: Nauka, 1965. - 309 C

8. Holl D., Rao K. Fotosintez. // M.: Mir, 1983. - $134 \mathrm{~s}$.

9. Blankenship R. E. Molecular Mechanisms of Photosynthesis. // Blackwell Science, Oxford-Paris, 2002. - $321 \mathrm{p}$.

10. Ladygin G., SHirshikova G. N. Sovremennye predstavleniya o funkcional'noj roli karotinoidov v hloroplastah eukariot. // ZHurnal obshchej biologii. 2006, t. 67, № 3, c 163-189.

11. Konev S.V. Fotobiologiya. // Izd-vo: Mn.: BCU. 1979. - 385c.

12. Makarenko O.A., Levickij A.P. Fiziologicheskie funkcii flavonoidov v rasteniyah. // Fiziologiya i biohimiya kul'turnyh rastenij. 2013, t. 45, № 2, c. 100-112.

13. CHervyakovskij V.P., Kurchenko V.A., Kostyuk E. M. Rol' flavonoidov v biologicheskih reakciyah s prenosom elektronov. // Trudy Belorusskogo gosudarstvennogo universiteta. Minsk. 2009. t. 4, chast' 1. - 19-s.

14. Tyureeva E.V., Dmitrieva V.A., Vojcekhovskaya O.V. Hlorofill b kak istochnik signalov, reguliruyushchih razvitie i produktivnost' rastenii. // Sel'skohozyajstvennaya biologiva. 2017, t. 52, v. 5, s. 843-855.

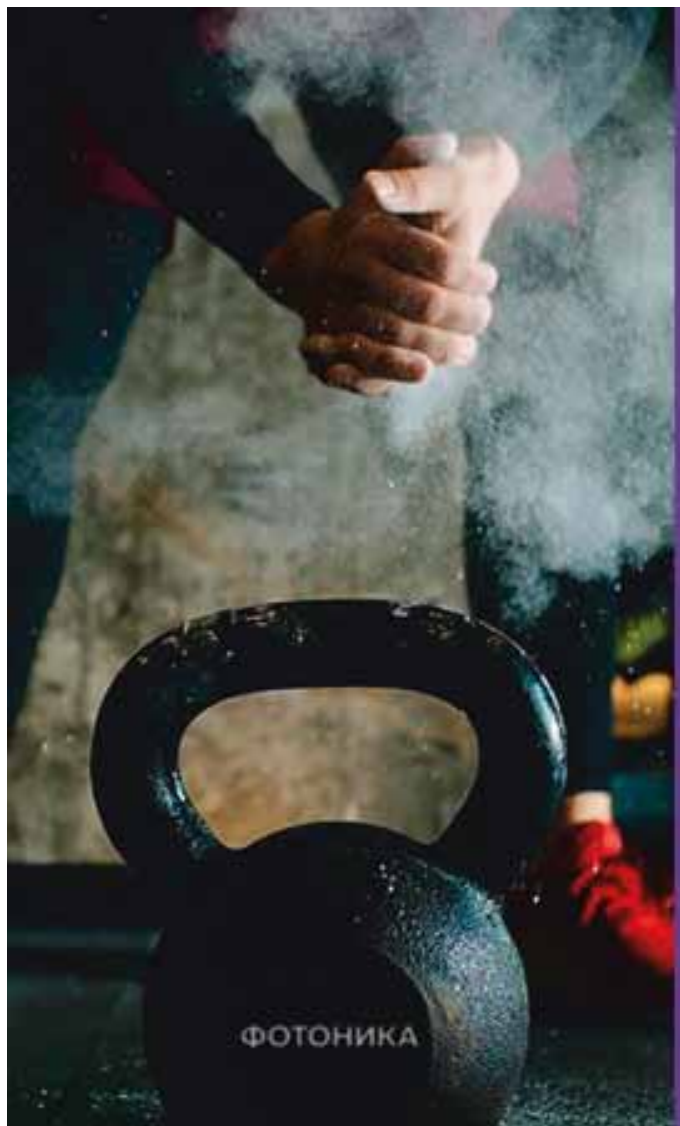

\section{Всероссийский Конкурс УМНИК-Фотоника}

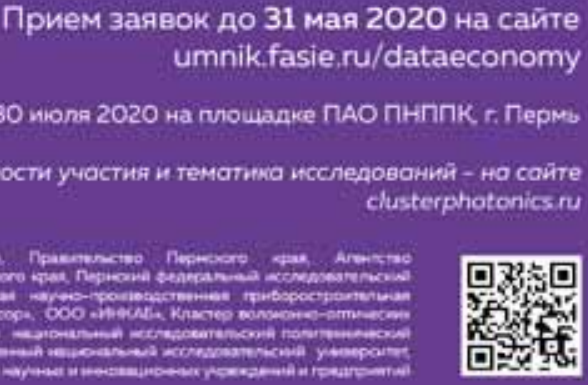




\section{№ 7, p.1957-1964.}

17. Фрайкин Г.Я. Белковые сенсоры света: фотовозбужденные состояния, сигнальные свойства и применение в оптогенетике. // М.: 000 "АР-Консалт", 2018 г. -87 C.

18. Синнот Э. Морфогенез растений / М: Изд-во иностр. лит., 1963. - 601 С.

19. Jigang Li, Gang Li,Haiyang W., Deng X.W. Arabidopsis Book. // 2011, 9: e0148. doi: 10.1199/tab.0148/

20. Costa G.V., Fankhauser C. Sensing the light environment in plants: photoreceptors and early signaling steps. // Current Opinion in Neurobiology. 2015., 34: p. 46-53.

21. Briggs W. R., Olney M. A. Photoreceptors in Plant Photomorphogenesis to Date. Five Phytochromes, Two Cryptochromes, One Phototropin, and One Superchrome, 2003 <http://www.plantphysiol.org/content/125/1/85.fus.

22. Кулаева О.Н. Как свет регулирует жизнь растений // Соросовский образовательный журнал. 2001, т. 7, № 4, с. 6-12.

23. Дерфлинг К. Гормоны растений. Системный подход. // М.: Мир, 1985. - 304 с

24. Цыганкова В. А., Галкина Л.А., Мусатенко Л. И., Сытник К. М. Генетический и эпигенетический контроль роста и развития растений. Гены биосинтеза ауксинов и ауксин-регулируемые гены, контролирующие деление и растяжение клеток растений. // Биополимеры и клетка. 2005. т. 21. № 2, с. 107-133.

25. Гэлстон А., Девис П., Сэттер Р. Жизнь зеленого растения // М.: Мир, 1983. $552 \mathrm{c}$.

26. Полевой В. В. Фитогормоны // Л.: Изд-во ЛГУ, 1982. - 248 с

27. Полевой В. В. Внутриклеточные и межклеточные системы регуляции у растений. // Соросовский образовательный журнал. 1997, № 9, с. 6-11.

28. Кулаева О. Н., Кузнецов В. В. Новейшие достижения и перспективы изучения механизма действия фитогормонов и их участия в сигнальных системах целого растения. // Вестник РФФИ. 2004, № 36, с. 12-36.

29. Муромцев Г. С., Агнистикова В. Н. Гиббереллины. М., 1984. - 208 с.

30. Роньжина Е.С. Цитокинины в регуляции донорно-акцепторных связей у растений. // Калининград: изд-во КГТУ, 2005. - 266 с.

31. Шевелуха В.С. Периодичность роста сельскохозяйственных растений и пути ее регулирования. // М.: Колос. 1980.-455с

32. Тихомиров А.А., Шарупич В. П., Лисовский Г. М. Светокультура растений: биофизические и биотехнологические основы. // Новосибирск: Изд-во СО РАН 2000. $-213 \mathrm{C}$.

33. Светодиоды и их применение для освещения / под редакцией Ю. Б. Айзенберга. // М: 3нак. 2011. - $280 \mathrm{C}$.

34. Kulchin Yu. N., Zmeeva V. N., Subbotin E. P., Kostyanko A. A. The Effect of Multispectral Light Emitting Diodes (LEDs) on the Activation of Morphogenic Processes in Cell Culture of Rice Oryza Sativa I / Defect and Diffusion Forum. Trans Tech Publications, Switzerland. 2018, v. 386, p. 236-243.

35. Gafitskaya I.V., Nakonechnaya O.V., Grishchenko O.V., Bulgakov V.P., Zhuravlev Yu. N., Subbotin E. P., Kulchin Yu. N. Growth of Solanum tuberosum plantlets in vitro under LED light sources. // Proc. SPIE11024, Asia-Pacific Conference on Fundamental Problems of Opto- and Microelectronics. 2017, 110240E (4 January 2019); doi: 10.1117 / 12.2314903.

36. Kulchin Yu. N., Nakonechnaya O.V., Gafitskaya I.V., Grinchenko O.V., Epifanova T. Yu., Orlovskaya I. Yu., Zhuravlev Yu. N., Subbotin E. P. Plant Morphogenesis under Different Light Intensity // Defect and Diffusion Forum. Trans Tech Publications, Switzerland 2018., v. 386, p. 201-206.

37. Гафицкая И. В., Наконечная О. В., Журавлев Ю. Н., Субботин Е. П., Кульчин Ю. Н. Перспективы использования светодиодного излучения при культивировании in vitro растений-регенерантов картофеляю. // Сборник материалов III научно-практической конференции с международным участием "Перспктивы фотобиотехнологии для улучшения квчества жизни на Севере». Якутск, Республика Саха (Якутия), Россияю. 2018 ., с 35-37.

38. Жилинский Ю. М., Кумин В.Д. Электрическое освещение и облучение. // М.: Колос. 1982. -268 с

39. Субботин Е. П.,. Гафицкая И. В, Наконечная О. В., Журавлев Ю. Н., Кульчин Ю. Н. Влияние искусственного солнечного света на рост и развитие растений-регенерантов Solanum tuberosum. // Turczaninowia. 2018., т. 21 (2), c. $32-39$.

40. Наконечная О. В., Гафицкая И. В., Бурковская Е. В., Хроленко Ю.А., Грищенко О. В., Журавлев Ю. Н., Субботин Е. П., Кульчин Ю. Н. Влияние интенсивности света на морфогенез Stevia rebaudiana в условиях in vitro. // Физиология растений. 2019, т. 66, № 4, с. 304-312.

41. Richard J. Mural Fundamentals of Light-Regulated Cene Expression // Plants Cenetic Engineering. / Ed. Biswas B. B., Harris. J. R. Springer Nature Switzerland AG. 2019., p. 191-211.
15. Baier M., Dietz K.J. Chloroplasts as source and target of cellular redox regulation: A discussion on chloroplast redox signals in the context of plant physiology. // Journal of Experimental Botany. 2005. v. 56, No. 416, p. 1449-1462.

16. Folta K.M., Childers K. S. Light as a Growth Regulator: Controlling Plant Biology with Narrow-bandwidth Solid-state Lighting Systems. // Hortscience.2008, v. 43, № 7, p.1957-1964.

17. Frajkin C.YA. Belkovye sensory sveta: fotovozbuzhdennye sostoyaniya, signal'nye svojstva i primenenie v optogenetike. // M.: 000 "AR-Konsalt», $2018 \mathrm{~g}$. - $87 \mathrm{~s}$.

18. Sinnot E. Morfogenez rastenij/ M: Izd-vo inostr. lit., 1963. $-601 \mathrm{~s}$.

19. Jigang Li, Gang Li, Haiyang W., Deng X.W. Arabidopsis Book. // 2011, 9: e0148. doi: 10.1199/tab.0148/

20. Costa G.V., Fankhauser C. Sensing the light environment in plants: photoreceptors and early signaling steps. // Current Opinion in Neurobiology. 2015., 34: p. 46-53.

21. Briggs W. R., Olney M.A. Photoreceptors in Plant Photomorphogenesis to Date. Five Phytochromes, Two Cryptochromes, One Phototropin, and One Superchrome, 2003 <http://www.plantphysiol.org/content/125/1/85.fu>.

22. Kulaeva 0. N. Kak svet reguliruet zhizn' rastenij // Sorosovskij obrazovatel'nyj zhurnal. 2001, t.7, № 4, s.6-12.

23. Derfling K. Cormony rastenij. Sistemnyj podhod. // M.: Mir, 1985. - 304 C

24. Cygankova V. A., Galkina L.A., Musatenko L. I., Sytnik K. M. Ceneticheskij i epigeneticheskij kontrol' rosta i razvitiya rastenij. Ceny biosinteza auksinov i auksinreguliruemye geny, kontroliruyushchie delenie i rastyazhenie kletok rastenij. // Biopolimery i kletka. 2005. t. 21. № 2, c. 107-133.

25. Gelston A., Devis P., Setter R. ZHizn' zelenogo rasteniya // M.: Mir, 1983. - 552 C.

26. Polevoj V.V. Fitogormony // L.: Izd-vo LCU, 1982. -248 s.

27. Polevoj V.V. Vnutrikletochnye i mezhkletochnye sistemy regulyacii u rastenij. // Sorosovskij obrazovatel'nyj zhurnal. 1997, № 9, s.6-11.

28. Kulaeva O.N., Kuznecov V.V. Novejshie dostizheniya i perspektivy izucheniya mekhanizma dejstviya fitogormonov $i$ ih uchastiya v signal'nyh sistemah celogo rasteniya. // Vestnik RFFI. 2004, № 36, s.12-36.

29. Muromcev G. S., Agnistikova V. N. Cibberelliny. M., 1984. - 208 C.

30. Ron'zhina E.S. Citokininy v regulyacii donorno-akceptornyh swyazej u rastenij. // Kaliningrad: izd-vo KGTU, 2005. - 266 c

31. SHeveluha B.C. Periodichnost' rosta sel'skohozyajstvennyh rastenij i puti ee regulirovaniya. // M.: Kolos. 1980.-455s.

32. Tihomirov A. A., SHarupich V.P., Lisovskij G. M. Svetokul'tura rastenij: biofizicheskie i biotekhnologicheskie osnovy. // Novosibirsk: Izd-vo SO RAN, 2000. - 213 C.

33. Svetodiody i ih primenenie dlya osveshcheniya / pod redakciej YU. B. Ajzenberga. // M: Znak. 2011. $-280 \mathrm{~s}$

34. Kulchin Yu. N., Zmeeva V.N., Subbotin E. P., Kostyanko A.A. The Effect of Multispectral Light Emitting Diodes (LEDS) on the Activation of Morphogenic Processes in Cell Culture of Rice Oryza Sativa I / Defect and Diffusion Forum. Trans Tech Publications, Switzerland. 2018, v. 386, p. 236-243.

35. Gafitskaya I.V., Nakonechnaya O.V., Grishchenko O.V., Bulgakov V.P., Zhuravlev Yu. N., Subbotin E.P., Kulchin Yu. N. Growth of Solanum tuberosum plantlets in vitro under LED light sources. // Proc. SPIEl1024, Asia-Pacific Conference on Fundamental Problems of Opto- and Microelectronics. 2017, $110240 \mathrm{E}$ (4 January 2019); doi: $10.1117 / 12.2314903$

36. Kulchin Yu. N., Nakonechnaya O.V., Gafitskaya I.V., Grinchenko O.V., Epifanova T.Yu., Orlovskaya I.Yu., Zhuravlev Yu. N., Subbotin E. P. Plant Morphogenesis under Different Light Intensity // Defect and Diffusion Forum. Trans Tech Publications, Switzerland 2018., v. 386, p. 201-206.

37. Gafickaya I.V., Nakonechnaya O.V., ZHuravlev YU.N., Subbotin E.P., Kul'chin YU.N. Perspektivy ispol'zovaniya svetodiodnogo izlucheniya pri kul'tivirovanii in vitro rastenij-regenerantov kartofelyayu. // Sbornik materialov III nauchno-prakticheskoj konferencii s mezhdunarodnym uchastiem «Perspktivy fotobiotekhnologii dlya uluchsheniya kvchestva zhizni na Severe». YAkutsk, Respublika Saha (YAkutiya), Rossiyayu. 2018 ., s35-37.

38. ZHilinskij YU. M., Kumin V.D. Elektricheskoe osveshchenie i obluchenie. // M.: Kolos. 1982. $-268 \mathrm{C}$.

39. Subbotin E.P.,. Gafickaya I.V, Nakonechnaya O.V., ZHuravlev YU. N., Kul'chin YU.N. Vliyanie iskusstvennogo solnechnogo sveta na rost i razvitie rastenijregenerantov Solanum tuberosum. // Turczaninowia. 2018., t. 21 (2), s. 32-39.

40. Nakonechnaya O.V., Gafickaya I.V., Burkovskaya E.V., Hrolenko YU.A., Grishchenko O.V., ZHuravlev YU. N., Subbotin E.P., Kul'chin YU. N. Vliyanie intensivnosti sveta na morfogenez Stevia rebaudiana v usloviyah in vitro. // Fiziologiya rastenii. 2019, t. 66, № 4, s. 304-312.

41. Richard J. Mural Fundamentals of Light-Regulated Cene Expression // Plants Cenetic Engineering. / Ed. Biswas B. B., Harris. J. R. Springer Nature Switzerland AG. 2019., p. 191-211. 


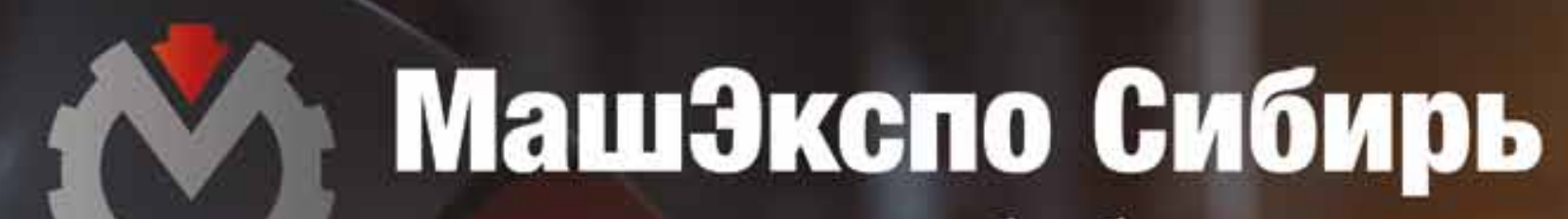

выставка металлообработки и сварки

- КРУПНЕЙШЕЕ ОТРАСЛЕВОЕ СОБЬТИЕ СИБИРИИ ДАЛЬНЕГО ВОСТОКА!

- БОЛЕЕ 70 ПРОИЗВОДИТЕЛЕЙИ ПОСТАВЩИКОВ ОБОРУДОВАНИЯИ МАТЕРИАЛОВ ДЛЯ МЕТАЛЛООБРАБОТКИ И СВАРКИ

- ЗДЕСЬ ВЕДУЩИЕ ПРОИЗВОДИТЕЛИСТАНКОВ, СВАРОЧНОГО ОБОРУДОВАНИЯВСТРЕЧАЮТСЯ С ПРЕДСТАВИТЕЛЯМИ КРУПНЫХ И СРЕДНИХ ПРОМЫШЛЕННЫХ ПРЕДПРИЯТИЙ.

- ДЕЛОВАЯ ПРОГРАММА ПОСВЯЩЕЕА АКТУАЛЬНЫМ ПРОБЛЕМАМ МАШИНОСТРОЕНИЯ

MASHEXPO-SIBERIA.RU MARK@SVKEXPO.RU
$+7 / 383 / 304-83-88$ ОРГАНИЗАТОР: ОOОЩСВК" 
TEХНОСФЕРА

РЕКЛАМНО-ИЗДАТЕЛЬСКИЙ ЦЕНТР

\section{0\% ГАРАНТИЯ ПОЛУЧЕНИЯ ВСЕХ НОМЕРОВ}

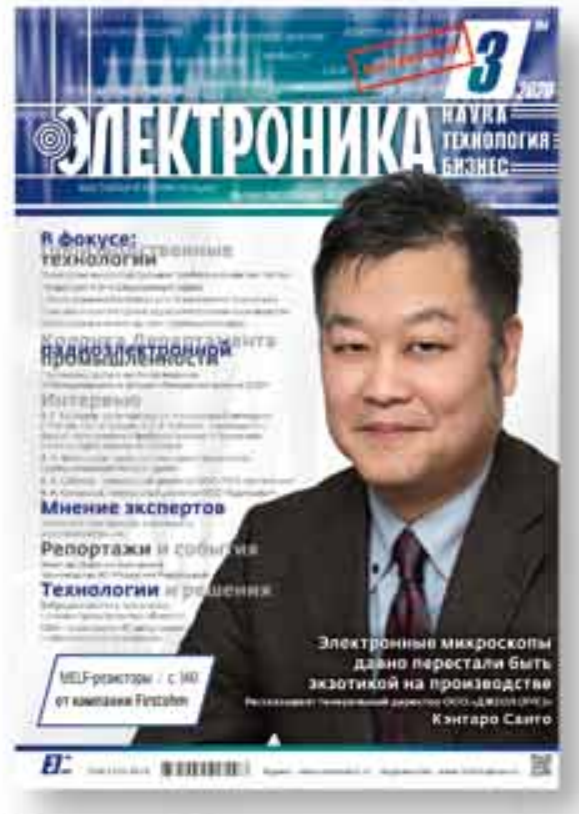

Стоимость 2200 p. за номер

Периодичность: 10 номеров в год www.electronics.ru

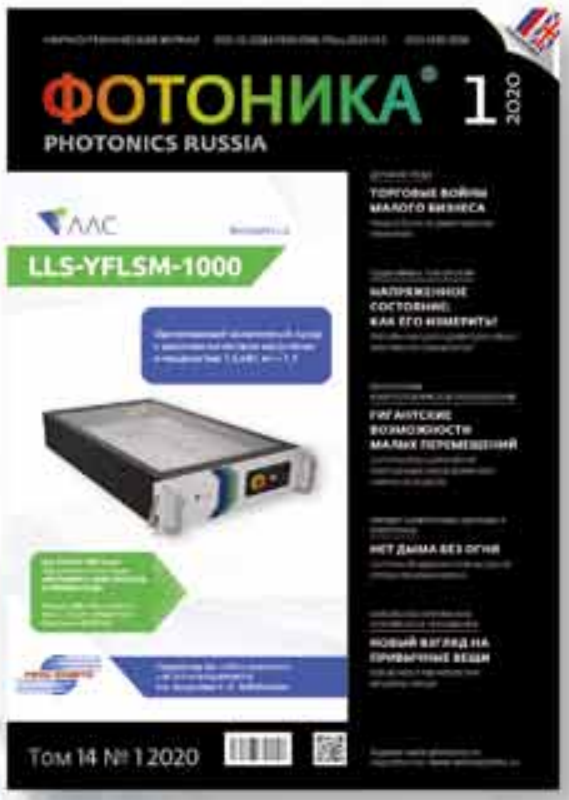

Стоимость 1430 р. за номер

Периодичность; 8 номеров в год www.photonics.su

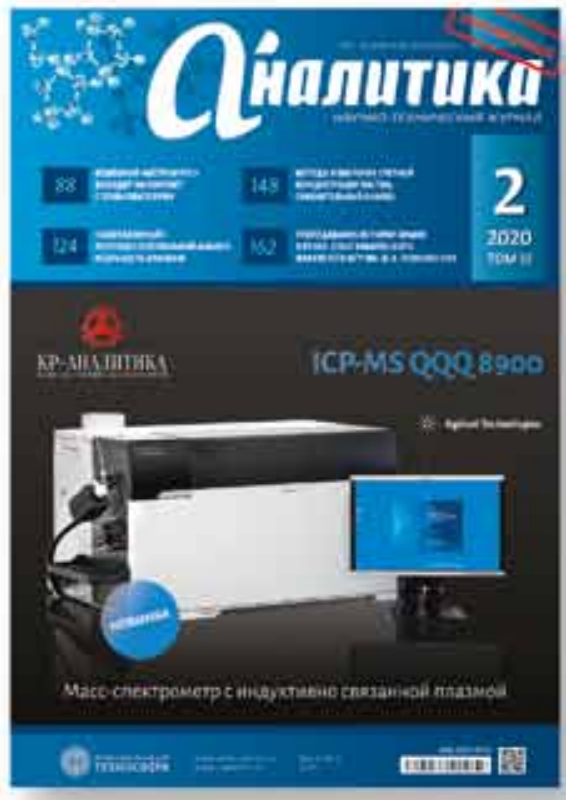

Стоимость 1430 р. за номер

Периодичность: 6 номеров в год www.j-analytics.ru

\section{ПОДПИСКА НА ХУРНАЛЫ}

www.technosphera.ru

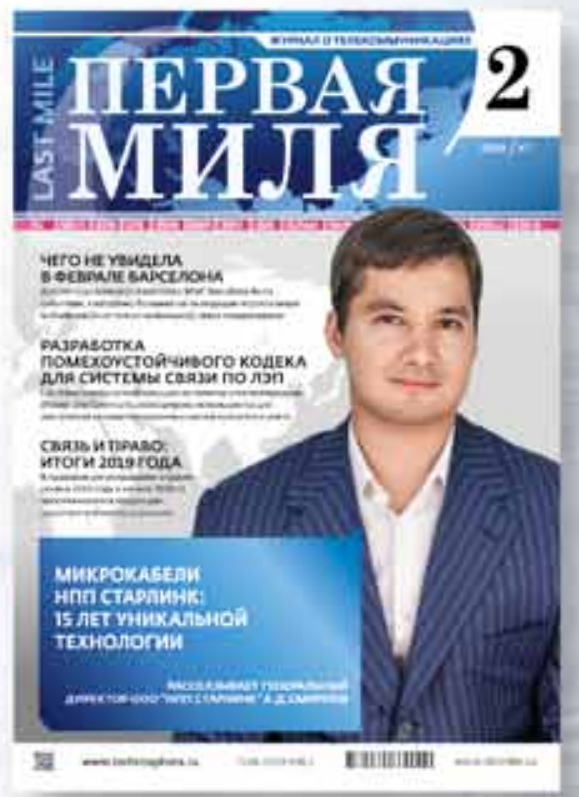

Стоимость 1056 р. за номер

Периодичность: 8 номеров в год www.lastmile.su

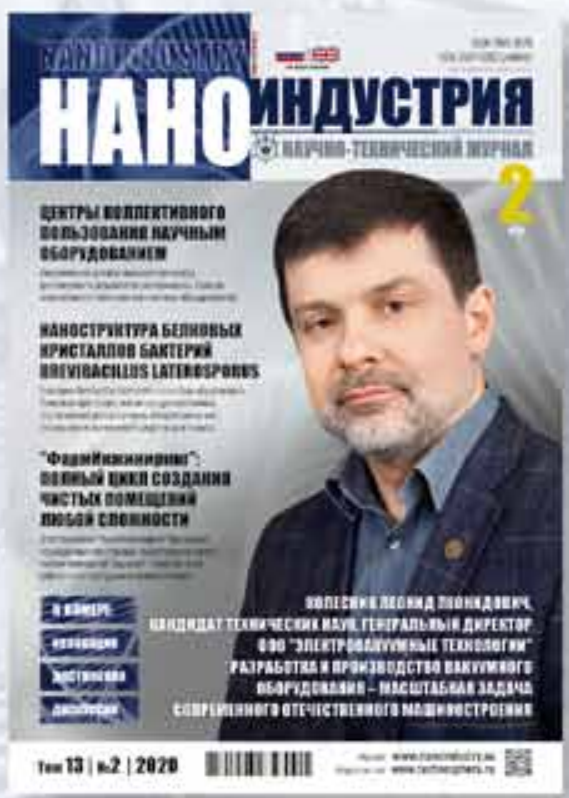

Стоимость 1287 p. за номер

Периодичность: 8 номеров в год

www.nanoindustry.su

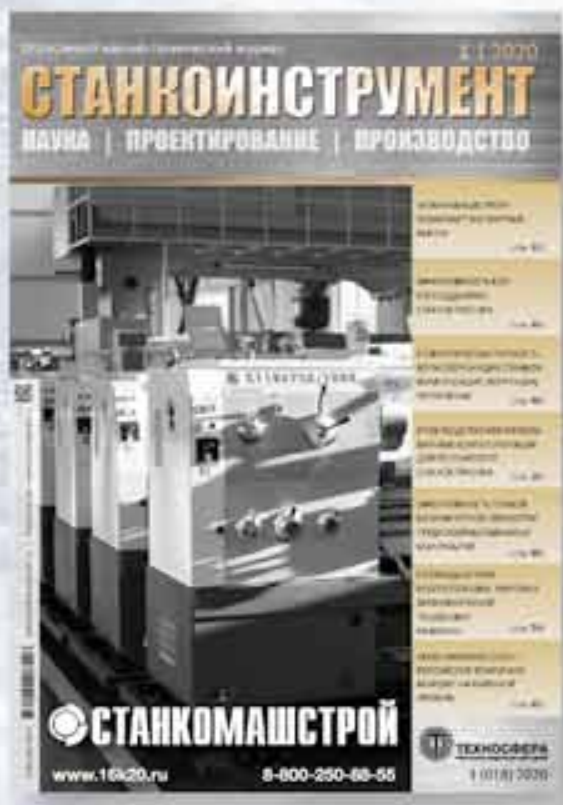

Стоимость 1716 р. за номер

Периодичность: 4 номера в год www.stankoinstrument.su 